\title{
Use and management of wild fauna by people of the Tehuacán-Cuicatlán Valley and surrounding areas, Mexico
}

Mariana Zarazúa-Carbajal 1,6, Michelle Chávez-Gutiérrez ${ }^{1}$, Yessica Romero-Bautista², Selene Rangel-Landa ', Ana Isabel Moreno-Calles², Luis Fernando Alvarado Ramos², Sandra E. Smith, José Blancas ${ }^{3}$, Ek del Val $^{1}$, María del Coro Arizmendi ${ }^{4}$ and Alejandro Casas $^{1 *}$ (i)

\begin{abstract}
Background: Interactions between humans and fauna lay in the heart of the history of human subsistence. In Mesoamerica, the Tehuacán-Cuicatlán Valley (TCV) harbours a high biodiversity with archaeological and ethnoecological evidence of its use by people inhabiting the area since at least 12,000 B.P. It is recognized as one of the most ancient areas of agriculture in the Americas, and a broad spectrum of management practices aimed to ensure the availability of desirable plants has been documented, but it has not been analysed for animals. This study aimed to investigate the use and management practices directed to wild animals along current settlements within the TCV and neighbouring areas.

Methods: We conducted an extensive search, review and analysis of documental sources for the period between 1967 and 2018. We found 38 documents providing information about the presence of animal species and 15 describing their use and/or management. We included our own observations from four case studies among the Ixcatec, Cuicatec, Nahua and Mestizo people, as well as from regional studies of biodiversity. We used unconstrained multivariate data analysis to describe the management typology of the animals in the region.

Results: Hitherto, 652 vertebrate species and 765 species of insects have been recorded in this area; and until present, 107 wild animal species have been reported to be used in 11 use-type categories, mostly for food (65.42\%), ornamental (27.52\%) and medicinal (21.10\%) purposes by the Nahua, Cuicatec, Popolocan, Ixcatec, Mazatec and Mestizo people. Their extraction entails manual capture and gathering as well as hunting and trapping strategies, some of them involving planning in time or space and communitarian regulations; in addition, relocation actions and care in captivity were recorded. Nearly 178 of the species distributed in the region with no reports of local use are used in other localities of Mesoamerica. Ethnozoological information is still lacking for the Mixtec, Chinantec and Chocholtec people in the area.

Conclusions: Wild fauna is still a valuable resource for the inhabitants of the TCV. Animals are obtained through extractive practices, which vary from one another in their qualitative attributes. With this work, we provide a context for further research priorities on fauna management in a region of high biocultural significance.
\end{abstract}

Keywords: Animal management, Biodiversity conservation, Domestication, Ethnozoology, Mesoamerican ethnobiology, Tehuacán-Cuicatlán Biosphere Reserve

\footnotetext{
* Correspondence: acasas@cieco.unam.mx

${ }^{1}$ Instituto de Investigaciones en Ecosistemas y Sustentabilidad, IIES,

Universidad Nacional Autónoma de México, Antigua Carretera a Pátzcuaro

8701, 58190 Morelia, Michoacán, Mexico

Full list of author information is available at the end of the article
}

(c) The Author(s). 2020 Open Access This article is distributed under the terms of the Creative Commons Attribution 4.0 International License (http://creativecommons.org/licenses/by/4.0/), which permits unrestricted use, distribution, and reproduction in any medium, provided you give appropriate credit to the original author(s) and the source, provide a link to the Creative Commons license, and indicate if changes were made. The Creative Commons Public Domain Dedication waiver (http://creativecommons.org/publicdomain/zero/1.0/) applies to the data made available in this article, unless otherwise stated. 


\section{Background}

Animals have been part of human life since its origins, representing sources of food, medicine, clothing, social, cultural, symbolic and spiritual benefits for humanity [1]. $\mathrm{Hu}-$ man groups integrate faunal elements to their subsistence systems through a broad range of practices [2], some of them, on one hand, involving control of the reproduction of successive generations and artificial selection processes of some animals that result in their domestication. On the other hand, people's practices might include the opportunistic extraction of animals through hunting or gathering. However, people may also take deliberate actions to ensure the availability of wild fauna, without necessarily involving a domestication process [2]. In order to improve the availability of desirable animals, these management actions might involve different ecological scales, from individuals to whole biotic communities [3] or even ecosystem processes.

Management practices include multi-scale decisionmaking and transformations in order to use, maintain or recover elements or functional processes of ecosystems [4]. In the case of fauna, these strategies can be focused on the animals themselves, from the individual to the population level, but also on elements or processes that support or influence them [2], such as their ecological mutualists (i.e. host plants, plants of their diet, plants pollinated and/or dispersed by them), preys and/or predators, and even manipulation of abiotic elements like water and fire [5]. The set of management practices can vary in the amount of energy and human effort invested, the presence of artificial selection, the control of the reproductive systems, and the extent of abiotic elements used, among others [6]. This variation can be pictured along a gradient of management "complexity" and/or "intensity" $[4,6]$.

The kind and intensity of management practices directed to animals depend on the motivations and the nature of the interactions between humans and fauna. Such interactions are modulated by both individual and social experiences and knowledge that are part of the complex of knowledge "corpus", beliefs "cosmos" and practices "praxis" known as traditional ecological knowledge or TEK [7, 8]. In Mesoamerica, a region recognized for its high biocultural richness $[9,10]$, and as one of the world's main centres of domestication and origins of agriculture [11], the wide spectrum of human-fauna interactions has configured a variety of processes and management practices. These, however, have not included the domestication of large mammals (i.e. for meat, milk or textile fibre production as well as draught animals) as in the Middle East, some other regions of Eurasia and the Andean Region [12].

The Mesoamerican spectrum of human-fauna interactions has included management strategies that resulted in the post-domestication selection of the dogs (Canis lupus familiaris Linnaeus, 1758) that arrived at the continent with human immigrations [12] and the domestication of the turkey (Meleagris gallopavo Linnaeus, 1758) [13]. However, a variety of animals have received human attention in several ways. One example is the systematic nurturing of insects (i.e. Dactylopius coccus Costa, 1829, Melipona spp. Illiger, 1906) [14, 15] and vertebrates (i.e. Ara militaris Linnaeus, 1766, Sylvilagus spp. Gray, 1987) [16-18]. Currently, along with the nurturing of these species and the adoption of introduced domesticates from all over the world (i.e. Apis mellifera Linnaeus, 1758, Capra hircus Linnaeus, 1758, Bos taurus Linnaeus, 1758, B. taurus indicus Linnaeus,1758, Ovis aries Linnaeus, 1758, Equus caballus Linnaeus, 1758, Gallus gallus Linnaeus, 1758, Sus scrofa scrofa Linnaeus, 1758, Cairina moschata Linnaeus, 1758 and other species of Anatidae), there is a range of extractive practices of wild animals. Some of them involve temporal captivity of individuals without breeding $[19,20]$, the active cultivation of "milpa" exclusively for prey attraction [3], favouring and caring for host plants in situ to increase the amount of insects gathered [21], the care on structures such as ant nests to maintain their availability [22], the spatial and temporal planning (i.e. hunting, fishing or gathering closures) to obtain a given resource and the formulation of communal and even religious regulations [23, 24], among others. All these strategies are intended to satisfy several human concerns.

Human needs for food and medicine are the main drivers of management, but in addition, factors like curiosity, beauty and empathy can also be relevant [20, 25]. Furthermore, actions are taken to reduce or prevent damages or losses that faunal elements may produce for subsistence systems or human health [26, 27]. Ethnobotanical evidence supports the hypotheses that management practices are primarily directed to increase the availability of those resources under a high demand pressure due to their high value for use, especially when resources are relatively scarce [6, 28-30]. However, the reduction in the risk of extirpation of a given resource after management might not always be successful, causing the loss not only of a biotic resource but also of the social and cultural activities related to it [30].

The analysis of the balance between the demand and the outcome of management practices to improve or maintain the availability of desirable animals is in the interest of developing the theory of integrated ecosystem management. With this work, we wanted to contribute with a first regional analysis of the contemporary use and management practices of fauna (i.e. excluding zootechnical methods used to the intensive breeding and exploitation of animals and their products, especially for the introduced varieties of animal domesticates from all over the world) by the indigenous and mestizo people 
within a region of Mesoamerica with high biocultural diversity, in which archaeological and ethnoecological evidence indicates the use and management of plants and animals for at least 12,000 years [4].

We aim to determine the number of species of wild animals that are used, and describe how they are used, the needs they satisfy, and the management practices involved in obtaining, maintaining or restoring the animal populations along a gradient of management intensity, in the Tehuacán-Cuicatlán Valley and neighbouring areas. We expected to find that wild animals continue being important elements of people's subsistence system in the region, that vertebrates are mainly used as food, medicine or pets [1], that edible insects are mostly represented by Coleoptera, followed by Hymenoptera, Hemiptera, Orthoptera and Lepidoptera, following the general tendency reported for Mexico [31-33]. Finally, we expected to find a variety of management practices devoted to wild fauna including reproduction in captivity, captive care without reproduction, protection of animals or their host plants in wild conditions, hunting and gathering.

\section{Methods}

\section{Study area}

The Tehuacán-Cuicatlán Valley (TCV) is an area of about $10,000 \mathrm{~km}^{2}$, located in south-eastern Puebla, northwestern Oaxaca and the limits of Veracruz [34, 35] (Fig. 1). A high environmental heterogeneity can be found in the area, with warm, semi-warm and temperate climates and average annual precipitation ranging from 400 to 700 $\mathrm{mm}$ [42]. The region is part of the Papaloapan River basin and comprises several valleys and mountain chains with elevations from 595 to $2950 \mathrm{~m}$ above the sea level [43]. The surrounding mountains, belonging to the physiographic regions known as "Sierras Orientales" and "Sierras Centrales de Oaxaca", harbour a gradient from thornscrub, tropical deciduous forest, oak forest, pine-oak forest in leeward slopes, and cloud forest and tropical rain forest in windward slopes [35]. The orographic shadow caused by the Sierra Madre Oriental prevents humidity from the Gulf of México and causes the arid condition of the TCV. The TCV is one of the five floristic provinces belonging to the Mexican Xerophytic Region in the Neotropical region

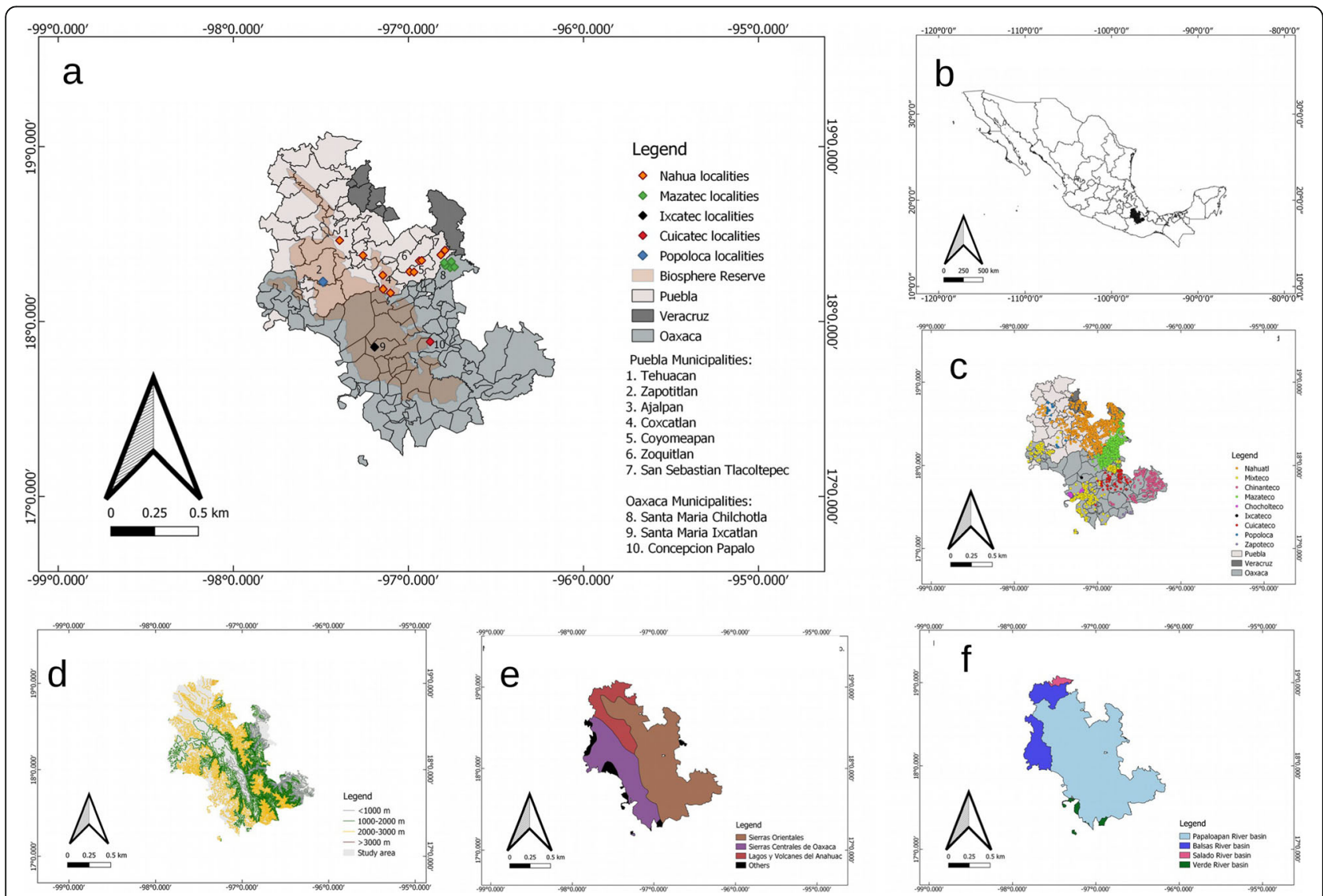

Fig. 1 Study area. a Political division of the study area in the Tehuacán-Cuicatlán Valley and surrounding regions showing indigenous localities with use or management of fauna records and the Tehuacán-Cuicatlán Biosphere Reserve. b Study area in the states of Puebla and Oaxaca, in central Mexico. c Distribution of indigenous languages in the localities within the study area following Ávila-Blomberg et al. [36]. d Elevation gradient in the study area. e Main physiographic regions within the study area following Cervantes-Zamora et al. [37] f Hydrological basins within the study area. The figures were elaborated in Qgis 3.8 [38] with data available from the website Geoportal CONABIO [36, 37, 39-41] 
[44]. At least 29 plant associations belonging to six general vegetation types have been recognized in this area, which stands out from other arid zones in North America for its high floristic diversity $[34,43]$ and its high species richness of mammals and birds [45].

The use and management of regional biodiversity have been part of the subsistence strategies of the human groups inhabiting the TCV for approximately, the last 14,000 years [46]. Wild plants and animals ranging from big vertebrates (i.e. antelopes, horses, deer) to insects have been part of the human diet since prehistoric times $[47,48]$. Archaeological records suggest that they were obtained through hunting, trapping and gathering [47]. The management of agroforestry systems, a current practice in the area $[49,50]$ is also millenary in the region [46]. The human groups currently inhabiting the Valley (i.e Ixcatec, Nahua, Cuicatec, Mixtec, Popolocan, Chocholtec, Chinantec, Mazatec and Mestizo) use over 2,000 of the more than 3,000 vascular plant species occurring in the TCV, and at least 610 of them are subject to management practices $[4,25]$. However, information regarding the current use and management of fauna by human groups in the area is not systematized. In 1998, a Biosphere Reserve of about 500,000 ha was decreed by the Mexican Federal Government Ministries SEMARNAT and CONANP [51] within the TCV. Within this Biosphere Reserve, an area of 145,255 ha was included in 2018 as a Mixed Site in the World Heritage List by the UNESCO because of its cultural and biological significance [52].

In our research, we included documented contemporary records of fauna occurring in any of the 107 municipalities (1436 localities) of the TCV and surrounding areas (Fig. 1a; the list of localities and municipalities is provided in the Additional file 1). We also included evidence from the archaeological records analysed by Kent V. Flannery, Eric O. Callen and Richard S. MacNeish [46-48].

\section{Documental and field research}

We conducted documental research between January 2018 and January 2019 for the available scientific literature about the occurrence, use and management of wild fauna in the studied region. Firstly, we consulted key documents (published between 1967 and 2018 according to the taxa) [47, 48, 51, 53-71]. Afterwards, we consulted the digital repositories of EBSCO, SCOPUS, Web of Knowledge and Google Scholar for subsequent records; in addition, those of specialized journals (Therya, Revista Mexicana de Biodiversidad, Acta Zoológica Mexicana, Etnobiología, Huitzil, Journal of Insects for Food and Feed, Journal of Ethnobiology and Ethnomedicine, Journal of Ethnobiology, Ethnobiology letters, Ethnobiology and Conservation); and those from dissertations of three Mexican universities
(UNAM, UAM, BUAP). Our search included 70 keywords in English and Spanish (Additional file 2). In order to collect the information, we considered the following criteria: (a) geographic: we included those records of the occurrence, use or management of fauna that felt within the study area (see Fig. 1 and text in the "Study area" section), (b) conceptual: for management, we took Zeder's approach and excluded works about zootechnical intensive management (see "Background" section), (c) time-line: all included records are subsequent to the research by Flannery, Callen and MacNeish 1967, (d) publication criteria: theses, dissertations, peer-reviewed journals, published abstracts and, in the case of fauna occurrence records, we included 7 databases hosted by CONABIO and GBIF). These criteria made possible to include practically all found works except for two sources that felt out of the geographical area and were instead considered in the references as other areas of Mesoamerica. We included records about the presence of fauna from 38 documentary sources (21 scientific reports published in peer-reviewed journals, seven public databases, four lists, three book chapters, two dissertations, one book) and registers about the use or management of this fauna from 15 documentary sources (five scientific reports published in peerreviewed journals, four dissertations, three book chapters, one book, one scientific dissemination article, one conference abstract). We also included primary information generated through the inventory of records of our own observations of living individuals, hunting evidence, and commercialization and interchange in the regional markets, as well as mentions in semi-structured interviews conducted with 30 Cuicatec households [72], 30 people in a mestizo locality with Popolocan ancestors in Zapotitlan, Puebla [73], 16 Ixcatec people in 2016, and with 16 people in three Nahua localities in Coyomeapan, Puebla (20182019). Additionally, we went through the checklist of species present in TCV with no local reports of use and checked their uses reported in other regions of Mesoamerica. This search based on the set of animal species whose presence has been reported so far within the TCV (references cited in Table 1). Specifically, if ethnozoological information for an animal species occurring in the study area but no information reported for the TCV region, we searched for at least one kind of use of the animal outside the TCV. This was done in order to analyse the supposition that in the TCV region, there would be more species under any use or management categories than those that have been documented so far. We included 38 documental sources (25 scientific reports published in peerreviewed articles, ten book chapters, one dissertation, one book, one scientific dissemination article). To avoid repeated information associated with synonymy, the nomenclature was checked with the Integrated Taxonomic Information System 2019 and 2000 [144]. 
Table 1 Number of animal species reported for the study area and the proportion of species used in the region and in other parts of Mesoamerica

\begin{tabular}{|c|c|c|c|c|c|}
\hline $\begin{array}{l}\text { Taxonomic } \\
\text { group }\end{array}$ & $\begin{array}{l}\text { P: Number of } \\
\text { species present } \\
\text { in the } \mathrm{VTC}^{\mathrm{a}}\end{array}$ & $\begin{array}{l}\text { Number of Orders, Families, } \\
\text { Genera, Species (UR) }{ }^{\mathrm{b}} \text { with } \\
\text { current use report in the VTC }\end{array}$ & $\begin{array}{l}\text { Number of Orders, Families, } \\
\text { Genera, Species }(U R O)^{c} \text { with } \\
\text { use report in other regions }\end{array}$ & $\begin{array}{l}\text { Species with use } \\
\text { reports in the } \\
\text { TCV (UR/P*100) } \\
(\%)\end{array}$ & $\begin{array}{l}\text { Species with use reports in } \\
\text { the TCV and other regions } \\
\left.((U R+U R O) / P)^{*} 100\right) \\
(\%)\end{array}$ \\
\hline Vertebrates & 652 & $25,51,74,75$ & $25,60,121,158$ & 11.50 & 35.73 \\
\hline Aves & 372 & $13,26,39,41$ & $16,37,81,107$ & 11.02 & 39.78 \\
\hline Mammalia & 133 & $9,17,24,27$ & $4,7,13,16$ & 20.30 & 32.33 \\
\hline Reptilia & 93 & $2,7,10,7$ & $3,10,20,26$ & 7.52 & 35.48 \\
\hline Amphibia & 38 & 0 & $2,6,7,9$ & 0.00 & 23.68 \\
\hline Actinopterigia & 16 & $1,1,1,2 \mathrm{Nd}$ & $\mathrm{Nd}$ & 1.25 & $\mathrm{Nd}$ \\
\hline Insecta & 765 & $5,19,33,32$ & $4,9,16,20$ & 4.18 & 6.79 \\
\hline Lepidoptera & 368 & $-, 7,11,11$ & $-, 4,11,15$ & 2.98 & 7.06 \\
\hline $\begin{array}{l}\text { Hymenoptera } \\
\text { (Apidae) }\end{array}$ & 262 & $-,-, 2,2$ & $-,-, 1,1,1$ & 0.01 & 1.14 \\
\hline $\begin{array}{l}\text { Hymenoptera } \\
\text { (Vespidae) }\end{array}$ & $\mathrm{Nd}^{*}$ & $-,-, 4,4$ & $\mathrm{Nd}$ & $\mathrm{Nd}$ & $\mathrm{Nd}$ \\
\hline $\begin{array}{l}\text { Hymenoptera } \\
\text { (Formicidae) }\end{array}$ & 31 & $-,-, 2,3$ & $-, 1,1,1$ & 9.67 & 12.90 \\
\hline Coleoptera & 72 & $-, 5,5,5$ & $-, 3,3,3$ & 6.94 & 11.11 \\
\hline Hemiptera & 24 & $-, 3,5,5$ & $\mathrm{Nd}$ & 20.83 & $\mathrm{Nd}$ \\
\hline Orthoptera & 8 & $-, 1,4,4$ & $\mathrm{Nd}$ & 50 & $\mathrm{Nd}$ \\
\hline
\end{tabular}

$N d^{*}$ : Not determined. a,b,c: References: ${ }^{a}$ Mammalia: [56-58, 74-81]; Reptilia and Amphibia: [47, 54, 59, 82-87]; Aves: [47, 51, 62, 73, 88-93]; Actinopterigia: [94]; Lepidoptera: [63]; Apidae: [64, 65, 95]; Formicidae: [66]; Coleoptera: [67, 68]; Hemiptera: [69, 96]; Orthoptera: [70]. List of species is not provided but see "References" section for the consulted literature)

b $[33,47,51,72,73,97-106]$, Rangel-Landa, Smith, Zarazúa and Chávez, this study. See Additional file 3 for a summarized list of the species and Additional file 4 to see the full records (in Spanish)

c $[31-33,107-143]$. See Additional file 5 for the list of species (in Spanish)

\section{Data analysis}

\section{Faunistic reports since 1967}

We calculated the proportion of used species per taxonomic Class, in relation to the total number of species of those classes recorded in the TCV since 1967, the date of publication of the studies by Kent V. Flannery in The Prehistory of the Tehuacan Valley [47]. We also estimated the proportion of species occurring in the TCV that, although not used in this area, are used somewhere else in Mesoamerica according to our literature review.

We grouped the reported uses in eleven categories: (1) edible: the animals that provide food, (2) ornamental: those used as decoration because of their beauty while alive or prepared after death, (3) medicinal: animals providing ingredients to be used in the attention of human health or childbirth, (4) weather indicator: cases in which the presence of an animal species or its phenotype is used as indicator of rain, temperature or seasonal changes, (5) ceremonial: animals used for ritual celebrations or religious purposes, (6) animal companion or pets: those required as companionship, beyond decoration or edible uses, (7) amulet: animals or their parts that bring good fortune and protection, (8) recreational: animals implied in human leisure with the exception of pets; an example is birdwatching, (9) tool: parts of the animal (for instance bones) that are used to facilitate a mechanical work, (10) crop protection: an animal, its parts or its secretions employed to protect cultivated plants against damages and (11) melliferous: animals producing honey consumed by humans. As an indicator of each species' relevance, we summed the number of use categories in which each species was recorded [145]. For medicinal fauna, we recorded the number of species used for each illness reported. Trochilidae Vigors, 1825 and Poeciliidae Bonaparte 1831 were analysed as Families while Sylvilagus spp. and Sciurus spp. Linnaeus, 1758 as Genera because their identification to a lower level is often not reported or has not been confirmed. Descriptive statistics were used to analyse information for all and each taxonomic Class.

Management practices were grouped into seven general categories: (1) manual capture and gathering: the manual collection of vertebrates or invertebrates, (2) hunting: the unplanned or minimally planned chasing and killing of animals, (3) care in captivity: maintaining and feeding animals in human areas while restricting animal movement capability, (4) planned gathering/hunting: these activities when involving the design of an agenda in time and space to capture the animals, the organization of participants and, sometimes, the establishing or attending of previously 
established agreements and restrictions, (5) enhancing: acts aimed to increase the presence of animals in situ, (6) relocation: transporting the animals into the desired place, in order to increase their numbers or to facilitate their collection or that of their products, and (7) trapping: the use of handmade cages or traps to capture animals. As an indicator of the variety of management forms for each species, we summed the number of management categories in which each species was recorded [145]. Basic descriptive statistics were calculated overall and for each taxonomic Class.

We recorded the vegetation types in which used fauna has been reported to occur in the $\mathrm{TCV}$, following Valiente-Banuet et al. [43]. We referred to the six main vegetation types identified by these authors (i.e. A-F) as: A: columnar cacti forest, B: lowland tropical deciduous forests (<1800 m), C: highland temperate (pine-oak) forests (> $1800 \mathrm{~m}$ ), D: riparian vegetation, E: xerophytic shrubland, F: shrubland. In accordance with our records, we also included cloud forest, tropical rain forest and sub-deciduous forest (see Table 1 for sources). If a species occurred in several vegetation types, we considered each of them.

Unconstrained principal component analyses (PCA) were performed to explore the variation of the used animal species $(n=71$, the complete checklist of species is provided in Additional file 3) according to three variables: (1) the number of use categories, (2) the number of management categories and (3) the number of cultural groups that use/manage the animal in the TCV region. In order to detect correlation among these numerical discrete variables, we performed Spearman correlation tests.

To analyse how the contribution of the animal management actions influences variation in the management typology, we performed an unconstrained PCA based on a presence/absence matrix. For constructing the presence/ absence matrix, we included the species as rows $(n=47)$, and the following ten variables as columns: (1) use of fire guns, (2) hunting in the milpa, (3) use of dogs, (4) use of traps, (5) manual capture and opportunistic gathering, (6) feeding in the wild and use of baits for attraction, (7) captivity, (8) planned gathering of individuals including communitarian regulations, (9) extraction of structures and (10) relocation of animals or structures. We excluded those species with no detailed information about management actions beyond a general category. PCA analyses were performed with the 'prcomp' function of the 'stats' package and the results were visualised with the 'factoextra' package of the $\mathrm{R}$ software $[146,147]$.

\section{Faunistic reports between 12,000 B.P and 500 B.P.}

We integrated a list of the animal species used and managed in the human subsistence systems of the TCV between 12,000 B.P. and 500 B.P. based on archaeological findings [46-48]. In this list, we included vertebrate species that were identified to be part of the human diet through signs of manipulation in bones, the age structure of the animal remains (i.e. deer, cottontail), and traces of projectiles and traps [47]. We, in addition, included insects inferred to be part of the diet based on the content of human coprolites [48], but we excluded coprolites containing remains of bones or hair to reduce the chances of reporting the diet of non-human mammals. We complemented the list with the type of uses mentioned in the ethnozoological research from 1967 [47] to 2019.

\section{Results \\ Use of the regional fauna}

Vertebrates in the TCV were represented by 652 species, nearly $11.50 \%$ of them reported as being used by people of the area. However, when including the uses reported for other regions of Mesoamerica, we found that $35.73 \%$ of the vertebrate species occurring in the TCV are potentially used as resources. Out of the 765 species of insects that have been reported in the TCV, only $4.18 \%$ was reported to be used in the region, but about $6.79 \%$ of them are used in other regions of Mesoamerica (Table 1).

Overall, the animals used in the TCV were found distributed in the following use categories: 70 edible species, 30 ornamental, 23 medicinal, 13 weather indicators; six are used as amulets, five as ceremonial or for rituals, four as animal companion and tools, respectively, three are melliferous, two are used for crop protection and one for recreational purposes (Table 2). The number of different uses per species ranges from 1 to 5 (all species mean $=1.54 \pm 0.08 \mathrm{SE}, n=109$; birds mean $=1.36 \pm$ $0.09 \mathrm{SE}, n=36$; mammals mean $=2.34 \pm 0.22 \mathrm{SE}, n=$ 26; reptiles mean $=1.14 \pm 0.14 \mathrm{SE}, n=7$; insects mean $=1.28 \pm 0.12 \mathrm{SE}, n=38$ ). The species with more uses reported are the naturalized bee Apis mellifera and the temazate deer Mazama temama Kerr, 1792 (Fig. 2). Bee's larvae are edible, honey is extracted, wax is used as glue, to elaborate candles with ceremonial motives and to make art pieces. The meat of the temazate deer is edible, the male reproductive structures are used to facilitate childbirth, heads and legs are prepared through taxidermic techniques to be used as ornaments and their skulls are exposed as a protection against "mal aire" (cultural illness or the agent that causes it).

We found evidence for treatments of at least twelve health issues, which involve animals (Table 3). Childbirth facilitation involves the use of $26.08 \%$ of the medicinal species, mainly mammals. Cancer treatment included 21.73\% of the species, mainly snakes and birds. Treatments for skin problems and epilepsy both involved $17.39 \%$ of the species. Mammals, snakes and immature stages of Lepidoptera are used in the treatment of skin problems while mammals, snakes and birds are used for alleviating epileptic seizures. Trochilidae (hummingbirds) is the family used for more 
Table 2 Number of animal species per use and management category, in the TCV and surrounding regions

\begin{tabular}{|c|c|c|c|c|c|c|c|c|c|c|c|c|c|c|c|c|c|c|}
\hline \multirow[b]{2}{*}{ Number of species } & \multicolumn{11}{|c|}{ Use categories $^{a}$} & \multicolumn{7}{|c|}{ Management categories $^{\mathrm{b}}$} \\
\hline & $\mathrm{E}$ & $\mathrm{O}$ & M & Wl & C & $\mathrm{R}$ & $A C$ & A & $\mathrm{T}$ & $\mathrm{CP}$ & ME & $C / G$ & $\mathrm{H}$ & CC & $P G$ & $\mathrm{E}$ & $\mathrm{R}$ & $\mathrm{T}$ \\
\hline Aves (41) & 13 & 16 & 4 & 12 & 1 & 1 & & 1 & & & & 14 & 13 & 13 & & 3 & & 2 \\
\hline Mammalia (27) & 21 & 14 & 12 & 1 & 1 & & 4 & 5 & 3 & 1 & & 6 & 19 & 6 & & & & \\
\hline Reptilia (7) & 4 & & 3 & & & & & & & & & 3 & 3 & & & & & \\
\hline Lepidoptera (11) & 11 & & 1 & & & & & & & & & 5 & & & 3 & & 1 & \\
\hline Hymenoptera Apidae (2) & 2 & 1 & & & 1 & & & & 1 & & 3 & 3 & & & & & & \\
\hline Hymenoptera Vespidae (4) & 4 & & & & 2 & & & & & & & 3 & & & & & & \\
\hline Hymenoptera Formicidae (3) & 3 & & 1 & & & & & & & 1 & & 2 & & & 1 & & 1 & \\
\hline Coleoptera (5) & 3 & & 1 & & & & & & & & & & & & & & & \\
\hline Hemiptera (5) & 5 & & & & & & & & & & & & & & 3 & & & \\
\hline Orthoptera (4) & 4 & & & & & & & & & & & 1 & & & & & & \\
\hline Total & 70 & 30 & 23 & 13 & 5 & 1 & 4 & 6 & 4 & 2 & 3 & 37 & 35 & 19 & 7 & 3 & 2 & 2 \\
\hline
\end{tabular}

aUse categories: E: Edible, O: Ornamental-Artisanal, M: Medicinal, WI: Weather indicator, C: Ceremonial-Ritual, AC: Animal companion, $A$ : Amulet, $T$ : Tool, CP: Use for crop protection, ME: Melliferous

${ }^{\mathrm{b}}$ Management categories: C/G: Manual capture and gathering, H: Hunting, CC: Care in captivity, PG: Planned gathering, E: Enhancing, R: Relocation, $T$ : Trapping. Neither use or management categories are exclusive from one another.

medical treatments. According to our ethnographic records in Coyomeapan, inhabitants of the region perceive that prior to the arrival of the vaccines in the 1970s, the use of birds and mammals to treat illnesses was much more common. An example of this is the larger former use of species of Trochilidae and Geomyidae Bonaparte, 1845 in remedies for whooping cough, especially for children.

Each species can be used by 1 to 4 human groups (mean $=1.65 \pm 0.09 \mathrm{SE}, n=93) ; 36$ species are used by the Mestizo people, 32 by the Cuicatec and the Nahua, respectively, 23 by the Ixcatec, 19 by the Mazatec and 13 by the Popolocan people. The animals used by more cultural groups of the region are the mammals Nasua narica
Linnaeus, 1766, Pecari tajacu Linnaeus, 1758, Sciurus spp. and Sylvilagus spp. (Fig. 3).

The animals used in any of the categories documented have been reported in at least eight vegetation types along the TCV (Table 4, Fig. 4). This information should be considered as potential systems from which fauna is extracted, rather than the actual systems from which it is extracted.

\section{General management categories}

Animals in the TCV region are obtained through extractive practices. We recorded the following general management categories:

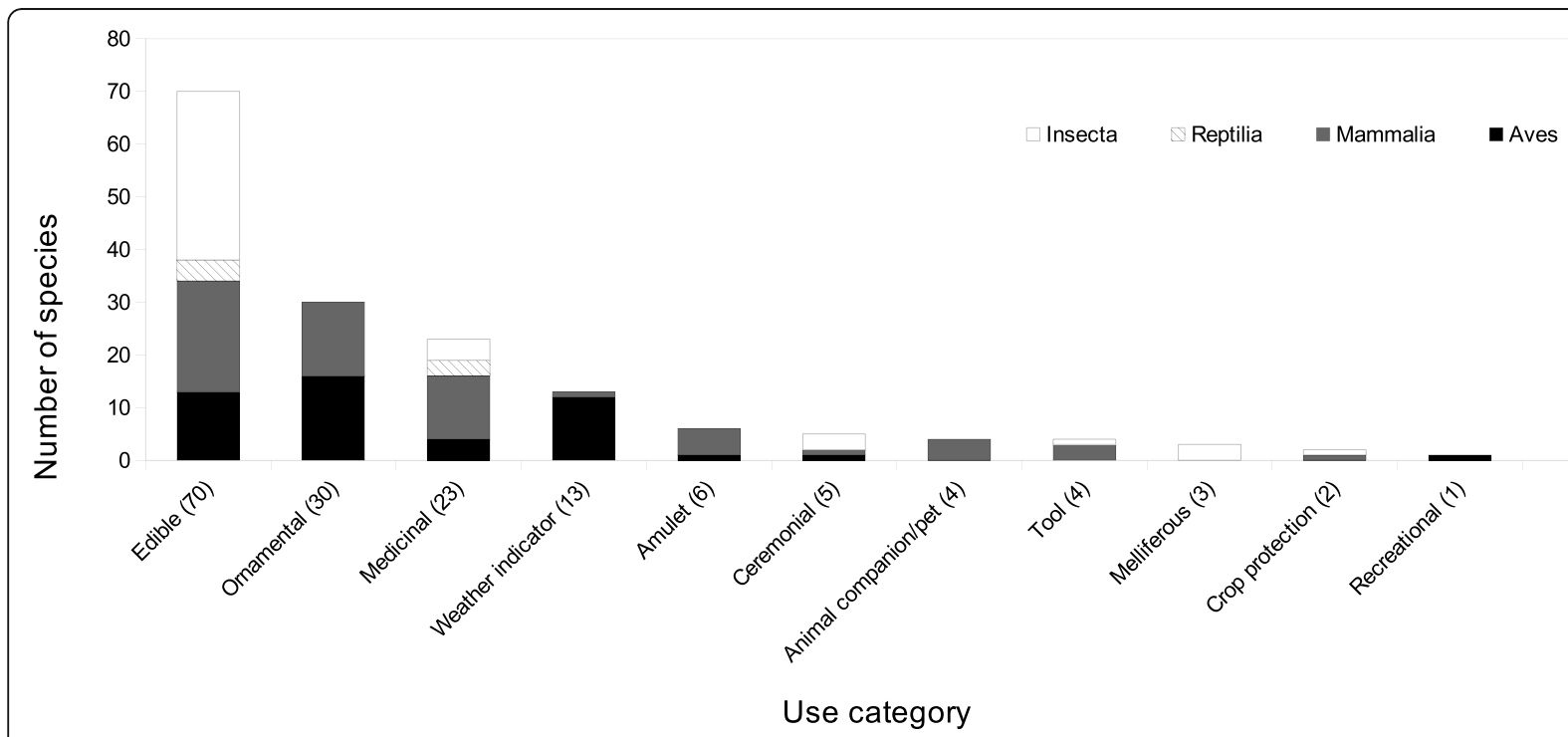

Fig. 2 Use categories for animals in the Tehuacán-Cuicatlán Valley and surrounding regions. Totals are indicated in parentheses 
Table 3 Healthcare and childbirth attention that involves animals, in the TCV and surrounding regions

\begin{tabular}{|c|c|c|c|c|c|c|}
\hline Health issue & $\begin{array}{l}\text { Cultural } \\
\text { group }\end{array}$ & $\begin{array}{l}\text { Animal } \\
\text { Class }\end{array}$ & Animal Family & $\begin{array}{l}\text { Number } \\
\text { of } \\
\text { species }\end{array}$ & $\begin{array}{l}\text { Total } \\
\text { number } \\
\text { of species }\end{array}$ & $\begin{array}{l}\text { Percentage of the total } \\
\text { number of medicinal } \\
\text { species }(n=23)\end{array}$ \\
\hline \multirow[t]{3}{*}{ Giving birth } & Nahua & Mammalia & $\begin{array}{l}\text { Dasypodidae Gray, 1821, Didelphidae Gray, 1821, } \\
\text { Tayassuidae Palmer, 1897, Erethizontidae Bonaparte, } \\
\text { 1845, Cervidae Goldfuss, } 1820\end{array}$ & 5 & 6 & 26.08 \\
\hline & \multirow[t]{2}{*}{ Cuicatec } & Mammalia & Dasypodidae, Didelphidae & 2 & & \\
\hline & & Aves & Psittacidae Rafinesque, 1815 & 1 & & \\
\hline \multirow[t]{3}{*}{ Cancer } & Nahua & Reptilia & Elapidae Boié, 1827, Viperidae Oppel, 1811 & 3 & 5 & 21.73 \\
\hline & Cuicatec & Reptilia & Viperidae & 1 & & \\
\hline & Mestizo & Aves & Cuculidae Leach, 1820, Corvidae Leach, 1820 & 2 & & \\
\hline \multirow[t]{4}{*}{ Dermatological } & \multirow[t]{3}{*}{ Nahua } & Mammalia & Dasypodidae & 1 & 4 & 17.39 \\
\hline & & Insecta & Hepialidae Stephens, 1829 & 1 & & \\
\hline & & Reptilia & Elapidae & 1 & & \\
\hline & Cuicatec & Mammalia & Mephitidae Bonaparte, 1845 & 1 & & \\
\hline \multirow[t]{4}{*}{ Epilepsy } & \multirow[t]{3}{*}{ Cuicatec } & Reptilia & Viperidae & 1 & 4 & 17.39 \\
\hline & & Mammalia & Mephitidae & 1 & & \\
\hline & & Aves & Trochilidae Vigors, 1825 & 1 & & \\
\hline & Mestizo & Aves & Cuculidae & 1 & & \\
\hline Antiophidic & Nahua & Reptilia & Elapidae, Viperidae & 3 & 3 & 13.04 \\
\hline \multirow[t]{2}{*}{ Whooping cough } & \multirow[t]{2}{*}{ Nahua } & Mammalia & Geomyidae Bonaparte, 1845 & 1 & 2 & 8.69 \\
\hline & & Aves & Trochilidae & 1 & & \\
\hline Hearth & Mestizo & Aves & Cuculidae, Trochilidae & 2 & & \\
\hline \multirow[t]{2}{*}{ Cultural ilnesses } & Cuicatec & Reptilia & Viperidae & 1 & 2 & 8.69 \\
\hline & Mestizo & Aves & Trochilidae & 1 & & \\
\hline \multirow{2}{*}{$\begin{array}{l}\text { Joint pain/ } \\
\text { inflammation } \\
\text { and rheumatism }\end{array}$} & Nahua & Mammalia & Canidae Fischer, 1817 & 1 & 1 & 4.34 \\
\hline & Ixcatec & Mammalia & Canidae & 1 & & \\
\hline Pain & Ixcatec & Insecta & Tenebrionidae Latreille, 1802 & 1 & 1 & 4.34 \\
\hline Antidepressant & Cuicatec & Insecta & Formicidae Latreille, 1802 & 1 & 1 & 4.34 \\
\hline Allergies & Cuicatec & Mammalia & Cervidae & 1 & 1 & 4.34 \\
\hline
\end{tabular}

Sources: [72, 73, 98, 101]; Rangel-Landa, Smith, Zarazúa and Chávez, this study

1) Hunting of vertebrates. it involves the chasing and/ or killing of animals valued as resources with the use of fire guns, slingshots or projectiles such as stones (the latter specially in the case of birds). It might include the aid of hunting dogs or the use of baits. Hunting is performed individually or in groups of family members or friends. In some cases, it is a nocturnal activity which involves waiting for the animals to approach in the milpa during the maize production season, or in areas like "huertas" (a type of homegardens that includes portions of forest located next to homes, where desirable elements of the biotic community are maintained and from which plants, mushrooms and wild fauna can be extracted) or the forest, where the animals feed. For instance, the hunting of deer (Odocoileus virginianus Zimmermann, 1780 and Mazama temama) is likely a social activity that involves small groups of men and one or two dogs, while the hunting of Cuniculus paca Linnaeus, 1766 is an individual task that involves waiting at night for the animal in its feeding place, sometimes using baits. People can also go out searching for certain animals such as reptiles, mammals or birds, but there is also opportunistic killing when the animals are seen during a trip, as frequently occurs with Didelphis spp. Linnaeus, 1758, Orthogeomys sp. Merriam, 1895, or Dasypus novemcinctus Linnaeus, 1758. Hunting is also a way to reduce the damage caused by wild animals to crops or domestic animals, as is the case of Orthogeomys sp., Nasua narica and Pecari tajacu, among others.

2) Trapping. in this category, we included the use of handmade cages or traps to capture animals. This is 


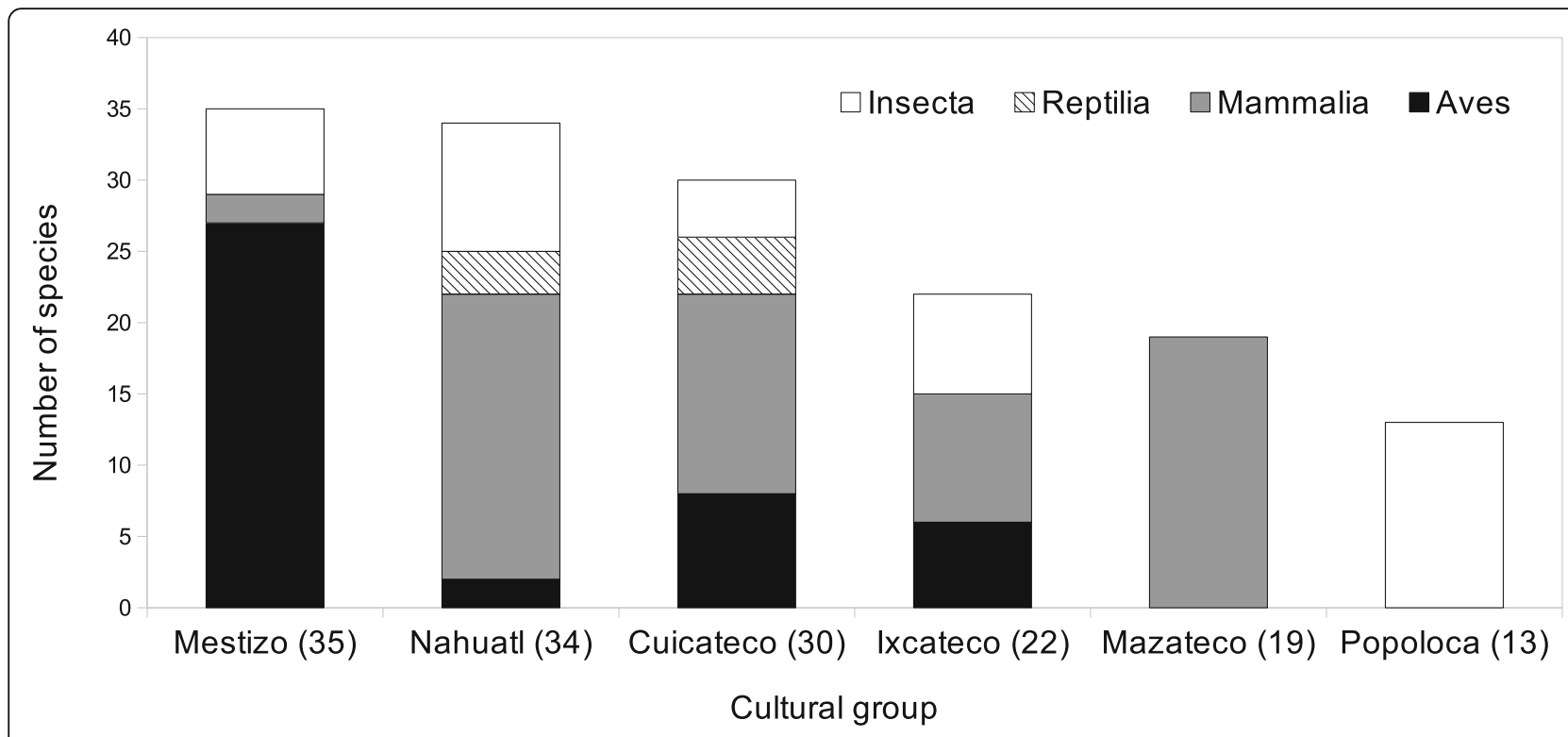

Fig. 3 Use of animals by different cultural groups in the Tehuacán-Cuicatlán Valley and surrounding regions. Totals are indicated in parentheses

the case for two Galliformes Temminck, 1820 in Nahua localities in Coyomeapan. We included this practice because a few people still perform this kind of capture; however, people interviewed considered that this practice was much more frequent in the past.

3) Manual capture/gathering. Within this category, we grouped birds and mammal species that are manually collected from their habitat as juveniles or eggs (birds, Sylvilagus spp., O. virginianus, $M$. temama, $U$. cinereoargenteus (Schreber, 1975), P. tajacu) and snakes which are captured alive with plastic bottles to prepare medicine (Fig. 5). We also included the non-regulated and non-planned gathering of insects. This is the case of the products of $A$. mellifera, Meliponini bees and wasp nests.

4) Relocation. It is a kind of gathering that involves collecting the animals and later transporting them to the desired place to increase their numbers, to facilitate their collection or that of their products, or to complete their development under surveillance. It is different from captivity since in relocation, people do not take active control of their feeding and movement. This is the case of the edible caterpillar Arsenura aff. armida (Cramer, 1779), which is gathered from Heliocarpus aff. velutina Rose, 1905 trees from the "acahual" and taken to an Heliocarpus

Table 4 Occurrence of used fauna in different vegetation types in the TCV and surrounding regions

\begin{tabular}{|c|c|c|c|c|c|c|c|c|}
\hline Vegetation type & Insecta & Reptilia & Aves & Mammalia & $\begin{array}{l}\text { Total number of } \\
\text { animal species }\end{array}$ & $\begin{array}{l}\% \text { of the total edible } \\
\text { species }(n=74)\end{array}$ & $\begin{array}{l}\% \text { of the total } \\
\text { ornamental species ( } n= \\
30 \text { ) }\end{array}$ & $\begin{array}{l}\% \text { of the total } \\
\text { medicinal species }(n= \\
\text { 23) }\end{array}$ \\
\hline $\begin{array}{l}\text { Lowland } \\
\text { tropical dry } \\
\text { forest }\end{array}$ & 8 & 3 & 24 & 14 & 49 & 35.13 & 73.33 & 56.52 \\
\hline $\begin{array}{l}\text { Highland } \\
\text { temperate } \\
\text { forest }\end{array}$ & 7 & 4 & 15 & 11 & 37 & 33.78 & 43.33 & 47.82 \\
\hline $\begin{array}{l}\text { Xerophytic } \\
\text { shrubland }\end{array}$ & 11 & 1 & 13 & 9 & 34 & 25.67 & 43.33 & 39.13 \\
\hline $\begin{array}{l}\text { Columnar cacti } \\
\text { forests }\end{array}$ & 2 & 0 & 23 & 1 & 26 & 12.16 & 43.33 & 21.73 \\
\hline Shrubland & 5 & 0 & 15 & 5 & 25 & 17.56 & 40 & 21.73 \\
\hline Cloud forest & 3 & 0 & 0 & 9 & 12 & 16.21 & 16.66 & 21.73 \\
\hline Rain forest & 3 & 0 & 0 & 7 & 10 & 13.51 & 13.33 & 13.04 \\
\hline $\begin{array}{l}\text { Subdeciduous } \\
\text { forest }\end{array}$ & 3 & 1 & 0 & 4 & 10 & 8 & 3.33 & 21.73 \\
\hline
\end{tabular}




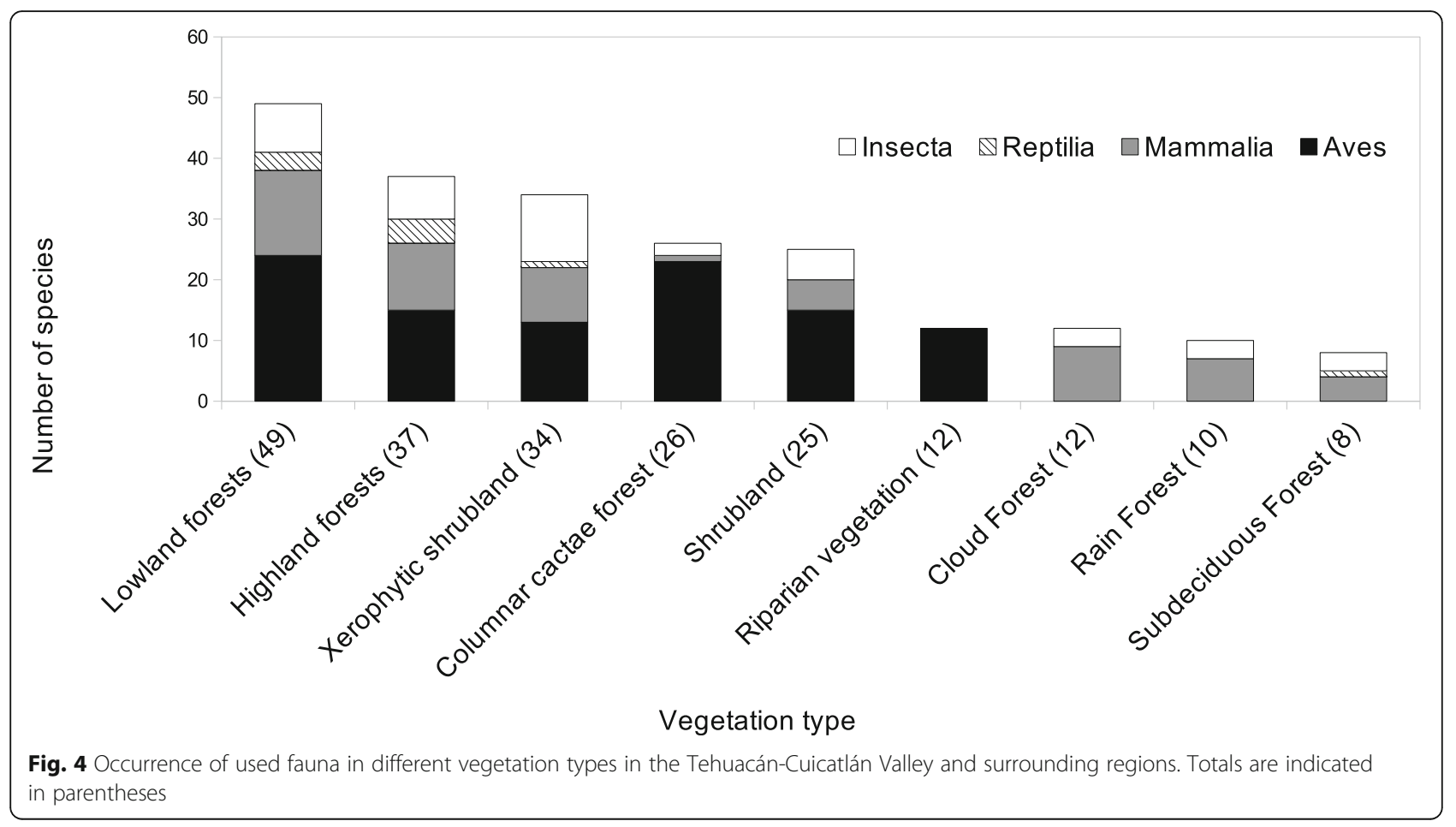

tree in homegardens to be taken care of. A family might deposit as much as hundreds of these animals in the same tree to assure their availability either for direct consumption by households or to sell them in the regional markets (nearly 20 caterpillars per U.S. Dollar). Atta mexicana (Smith 1858) colonies are also relocated to desirable places because the soil they bring to the surface is valued as a plant fertiliser. a)
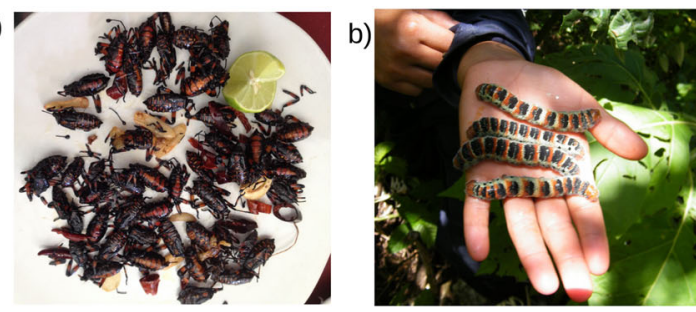

d)

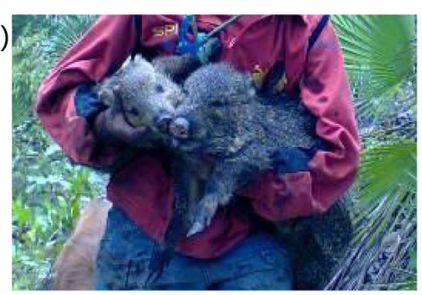

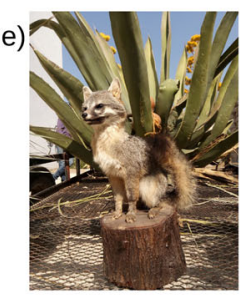

c)
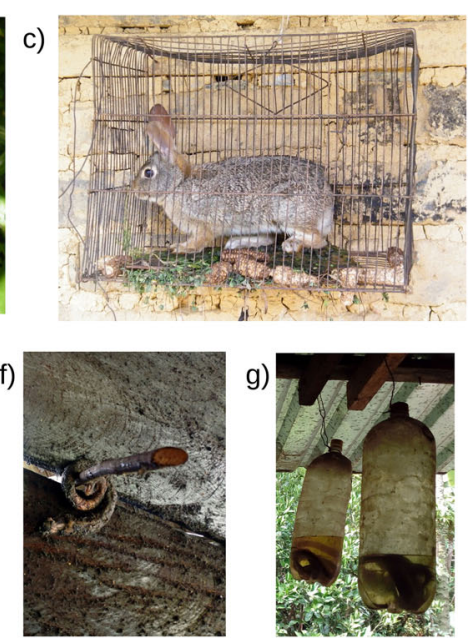

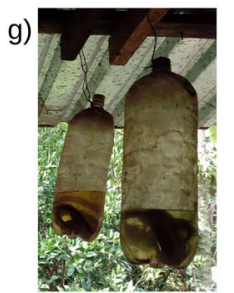

Fig. 5 Examples of animals managed by people in the Tehuacán-Cuicatlán Valley and surrounding areas. a Thassus gigas (Hemiptera). The gathering of this edible insect from its host Prosopis laevigata involves planification, in contrast to the gathering of other insects that is performed in an opportunistic way, in a Popolocan locality. b Arsenura armida (Lepidoptera). Groups of this caterpillar "Cuetla" are gathered and then relocated in an Heliocarpus aff. velutina tree beside a family home, in Nahua localities. c Sylvilagus spp. (Lagomorpha). Juveniles are captured and maintained in captivity even for years, in Nahua localities. d Pecari tajacu (Artiodactyla). Juveniles are maintained in captivity in an Ixcatec locality. e Urocyon cinereoargenteus (Carnivora) is hunted and used as food in a Cuicatec locality. It is also considered to play pranks to pulque producers in the localities of Tehuacán. This picture shows one of them prepared with taxidermic techniques and exhibited in "La feria del Pulque", Santa Ana Teloxtoc, 2019. f Didelphis spp. (Didelphimorphia) is hunted to prevent damages to domestic animals but also because of the use of its tail in childbirth in Nahua localities. $\mathbf{g}$ Snakes are captured alive and kept in alcohol to be used as antivenom, among other medical applications, in Nahua localities. Credits: a, e: SRL; d: FB; b, c, f, g: MZC 
5) Planned gathering. It involves a planned and scheduled strategy to collect individuals or structures (i.e. bee and wasp combs, ant nests), sometimes also involving common agreements about gathering restrictions in time and/or space. It differs from other gathering actions that are more casual or opportunistic and non-regulated. This is the case of a few species of insects such as Thasus gigas (Klug in Burmester 1835), Euschistus sp. Dallas, 1851, Mormidea notulata (Herrich-Schäffer, 1844) (Hemiptera) and Ormiscodes (Paradirphia) fumosa Felder,1874 (Lepidoptera). It is also the case of the maguey worm Aegiale hesperiaris Walker, 1985 (Lepidoptera), whose recollection is restricted to a few days per year in some localities, to avoid overexploitation of this highly valued resource.

6) Enhancing. It refers to acts aimed to attract the animals by feeding them in the wild. It differs from relocation since the animals are not actively transported from one place to another but, rather, they are attracted to a certain location. This is the case of the birds Columbina passerina Linnaeus, 1758, Columbina inca Lesson, 1847 and Zenaida macroura (Linnaeus, 1758).

7) Care in captivity. It refers to activities to ex situ maintain animals, involving actions to control their feeding and restricting their movement capability. It does not involve the reproduction of the animal or the manipulation of its reproductive system.

Animals that are maintained in captivity include the mammals Sylvilagus spp., Sciurus spp., P. tajacu, Procyon lotor (Linnaeus, 1758), Dasyprocta mexicana Saussure, 1860, juvenile individuals of $O$. virginianus and M. temama and ornamental birds. The individuals are often taken from their habitat as juveniles to be grown ex situ, in a family home. However, some of these animals often die in captivity after days or few weeks except for Sylvilagus spp., Sciurus spp. and birds, which can remain captive for years.

These general categories are non-exclusive, and a single species can belong to several of them. An ordination of the species along ten variables of management actions within these general categories showed that the first principal component explains $28.10 \%$ of the variance and is mainly related to hunting, while the second principal explains $19.50 \%$ of the variance and is mainly related to captivity and different types of capture and gathering (Tables 5, 6; Fig. 6). Mammals like Sylvilagus spp., Sciurus spp. and $P$. tajacu, among others (upper right quadrant in the biplot) are maintained in captivity, but also hunted in several ways. Mammals like Orthogeomys sp., U. cinereoargenteus, Canis latrans Say,
1823, and species of Galliformes are or were captured using traps, but they can also be hunted (lower right quadrant in the biplot). Insects and juvenile birds are manually collected, and these can involve regulated captures, extraction of nests or honeycombs, and relocation of individuals or structures (lower left quadrant in the biplot).

The number of management categories per species ranges from 1 to 4 (all animals mean $=1.51 \pm 0.08 \mathrm{SE}, n=$ 71 ; birds mean $=1.76 \pm 0.16 \mathrm{SE}, n=26$; mammals mean $=1.61 \pm 0.16 \mathrm{SE}, n=21$; reptiles mean $=1 \pm 0 \mathrm{SE}, n=6$; insects mean $=1.27 \pm 0.13 \mathrm{SE}, n=18$ ) (Table 2, Fig. 7).

The ordination of species along with the number of uses, the number of management categories and the number of cultural groups suggested correlation among these three variables but this was only significant between the number of uses and cultural group $\left(r_{\mathrm{s}}=0.586\right.$, $n=71, p$ value $<0.001)$. The first principal component explained $59.84 \%$ of the variance and the second one $26.69 \%$. Most of the variation along the first principal component is given by the differences in the number of uses and the number of cultural groups that use the species. Variation in the number of management categories was explained by the first and the second principal components (Fig. 8, Table 7). In the right half of the biplot are the species with more types of uses, more types of management and which are used by more cultural groups. The species related to more types of management practices such as doves, the edible Lepidoptera larvae $A$. armida, the temazate deer ( $M$. temama), cottontail rabbits (Sylvilagus spp.) and P. tacaju are concentrated in the upper right quadrant of the biplot.

Animal use and management from 12,000 B.P. to 500 B.P. Early settlers in the region integrated vertebrates and insects to their diet since before 12,000 B.P. Although the dates have been subject to discussion, the history of animal use in the TCV proposed by MacNeish, Flannery and Callen remains useful to characterise the general chronology of events. At least 20 of the species reported by these authors are still currently used in the area (Table 8).

According to the chronology reported, there is evidence of hunting and edible use of an American horse (Equus sp.) Linnaeus, 1758 and an antelope (Antilocapridae, probably Antilocapra americana (Ord, 1815)) about 12,000 B.P. along with small prey such as jackrabbits (Lepus sp. Linnaeus, 1758), coyotes (C. latrans), skunks (Spilogale sp. Gray, 1865, Conepatus sp. Gray, 1837), foxes (Urocyon sp. Baird, 1857), ring-tailed cats (Bassariscus astutus (Lichtenstein, 1830)), squirrels and turtles. Later, horses and antelope were extirpated from the area. From 10,000 B.P., the white-tailed deer (O. 
Table 5 Results of the principal component analysis showing eigenvalues and explained variance for management actions

\begin{tabular}{llll}
\hline Component & Eigenvalue & $\begin{array}{l}\text { Explained } \\
\text { variance (\%) }\end{array}$ & $\begin{array}{l}\text { Cumulative explained } \\
\text { variance (\%) }\end{array}$ \\
\hline PC1 & 2.81 & 28.10 & 28.10 \\
PC2 & 1.95 & 19.50 & 47.60 \\
PC3 & 1.29 & 12.92 & 60.53 \\
PC4 & 1.03 & 10.33 & 70.86 \\
PC5 & 0.91 & 9.19 & 80.05 \\
\hline
\end{tabular}

virginianus) appears in the archaeological record as hunted and consumed by humans, along with cottontails, lizards, skunks and other small prey. According to MacNeish, Flannery and Callen, small preys were probably obtained by trapping. Ants and immature stages of Lepidoptera were found in coprolites dated between $8500-7000$ B.P. and 7000-5500 B.P., respectively, in the Coxcatlán area. Between 7000 and 4300 B.P., hunting of the white-tailed deer seems to have intensified, and there was also hunting of $P$. tajacu and trapping of small games. Around 5000 B.P., the domestic dog (C. lupus familiaris) was introduced into the area. Between 4300 and 3500 B.P., remains of dogs with evidences of human consumption increased. Between 3000 and 1800 B.P., gophers increased in the archaeological record. Then, around 1500 B.P., the first turkey (M. gallopavo) appeared in the area.

\section{Discussion}

As we expected, fauna continues to be an important element of human culture and subsistence in the Tehuacán Valley, and the main use given to wild animal species, both vertebrates and invertebrates is for food. According to our field observations, this happens even in the presence of edible domesticates such as turkeys, chickens, pigs, goats and lambs.
The number of animal species used in the TCV as food, ornament and medicine is low compared with the number of plant species used for those purposes, but their proportions and importance are similar in these main use categories. Medicinal use of plants (396 species) is followed by edible (339 species) and ornamental (313 species) [4]. However, the fact that at least 874 plant species in the TCV are used as fodder [4], reflects the human interest in feeding animals in this region during the last five centuries.

Birds are the main taxonomic group that represents ornamental species, making this category the second in importance for edible purposes after mammals. This information comes mostly from the dry forests of the arid zone of the TCV [73]. Use and commercialization of living birds as ornamental is a complex activity that has a long tradition in Mexico and involves human specialization, organization and regulations at various levels from individuals and families, to non-profit associations and governmental policies [107]; however, with a few exceptions, breeding is not part of the management strategy for ornamental species [148]. So far, this is the case in the TCV.

The medicinal category was the third in the number of animal species and follows the tendency for Latin America, where the two groups with the larger numbers of medicinal species are mammals and birds [149]. We hypothesise that their uses can be taken as indicators of human health needs in the area. The presence of institutional medical attention could be resulting in the decrease in the use of animals to alleviate illnesses, as it has been reported for the use of medicinal plants in Ixcatlán [25]. In the Nahua localities of Coyomeapan, snakes are important components of the domestic first aid kit. They are used as antivenoms in a similar manner to that previously documented in localities of Brazil, where, in absence of antivenom treatments, coral snakes were introduced alive in brandy, and this brandy was then ingested to act as a preventive antivenom [150]. The alcohol used in the TCV

Table 6 Scores of the management action variables in 5 principal components

\begin{tabular}{|c|c|c|c|c|c|}
\hline Variable & PC1 & PC2 & PC3 & PC4 & PC5 \\
\hline Fire guns & 0.88 & -0.19 & -0.03 & 0.10 & -0.11 \\
\hline Milpa & 0.66 & 0.09 & 0.56 & -0.05 & -0.13 \\
\hline Dogs & 0.76 & 0.01 & 0.36 & 0.22 & 0.17 \\
\hline Traps & 0.32 & -0.32 & -0.57 & 0.22 & -0.32 \\
\hline Manual capture and gathering & -0.65 & 0.57 & 0.03 & 0.30 & 0.03 \\
\hline Feeding in the wild & -0.02 & 0.47 & 0.09 & -0.38 & -0.76 \\
\hline Captivity & 0.12 & 0.78 & 0.20 & 0.03 & 0.18 \\
\hline Planned gathering & -0.38 & -0.62 & 0.30 & -0.49 & 0.11 \\
\hline Extraction of structures & -0.37 & -0.26 & 0.27 & 0.63 & -0.29 \\
\hline Relocation & -0.40 & -0.39 & 0.53 & 0.15 & -0.18 \\
\hline
\end{tabular}




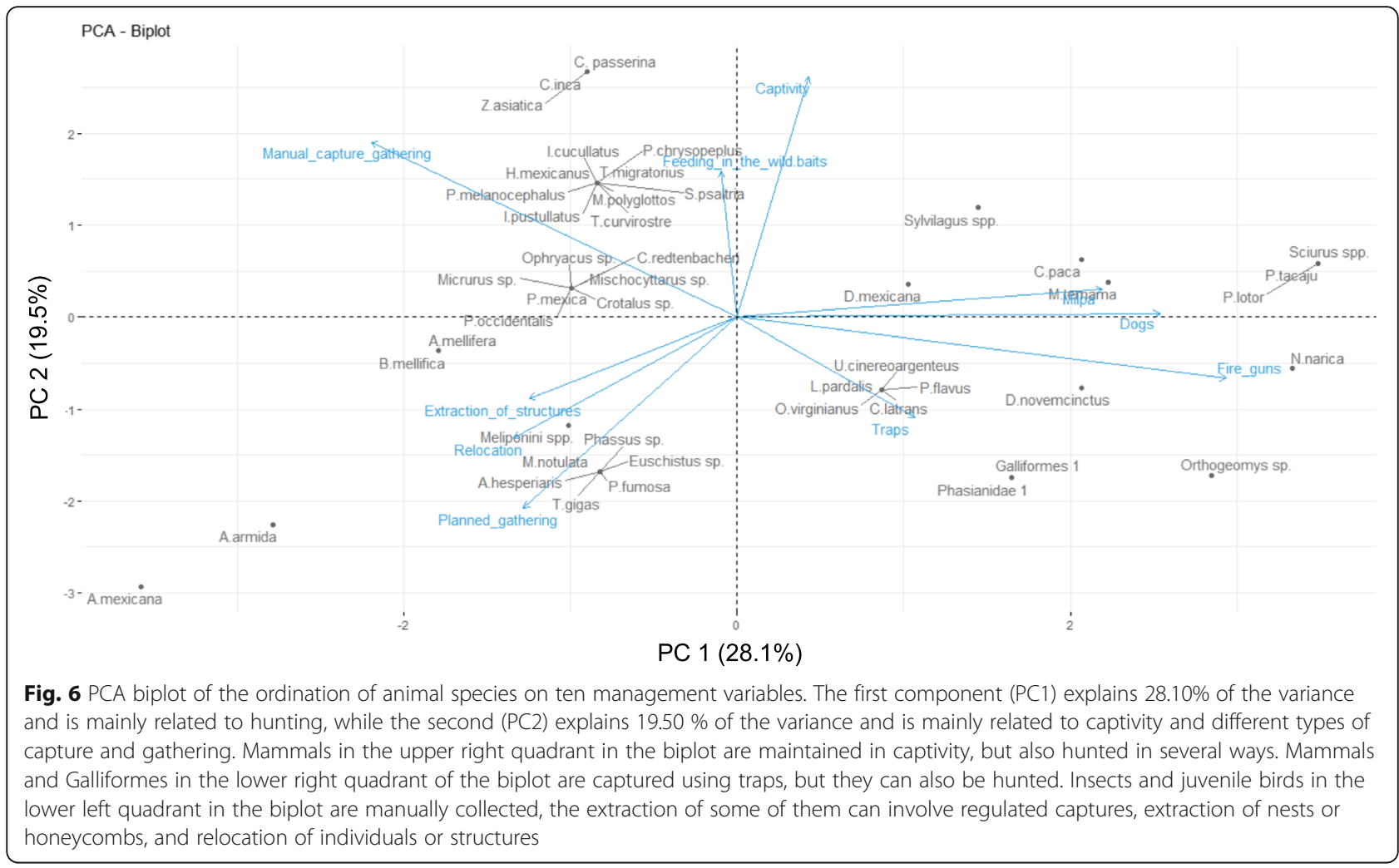

is made of sugarcane, whose preparation was introduced after the Spanish conquest, and it is also used to preserve the tails or glands of mammals used in other treatments. An especially interesting situation is observed for childbirth attention. Frequently, infusions of animal tails or reproductive parts are used to induce nausea in women and thereafter, contractions. Didelphis spp. was the genus most widely used for this purpose in the region, even for animals' birth. However, there is no consensus regarding its regional use since in some localities, other mammals

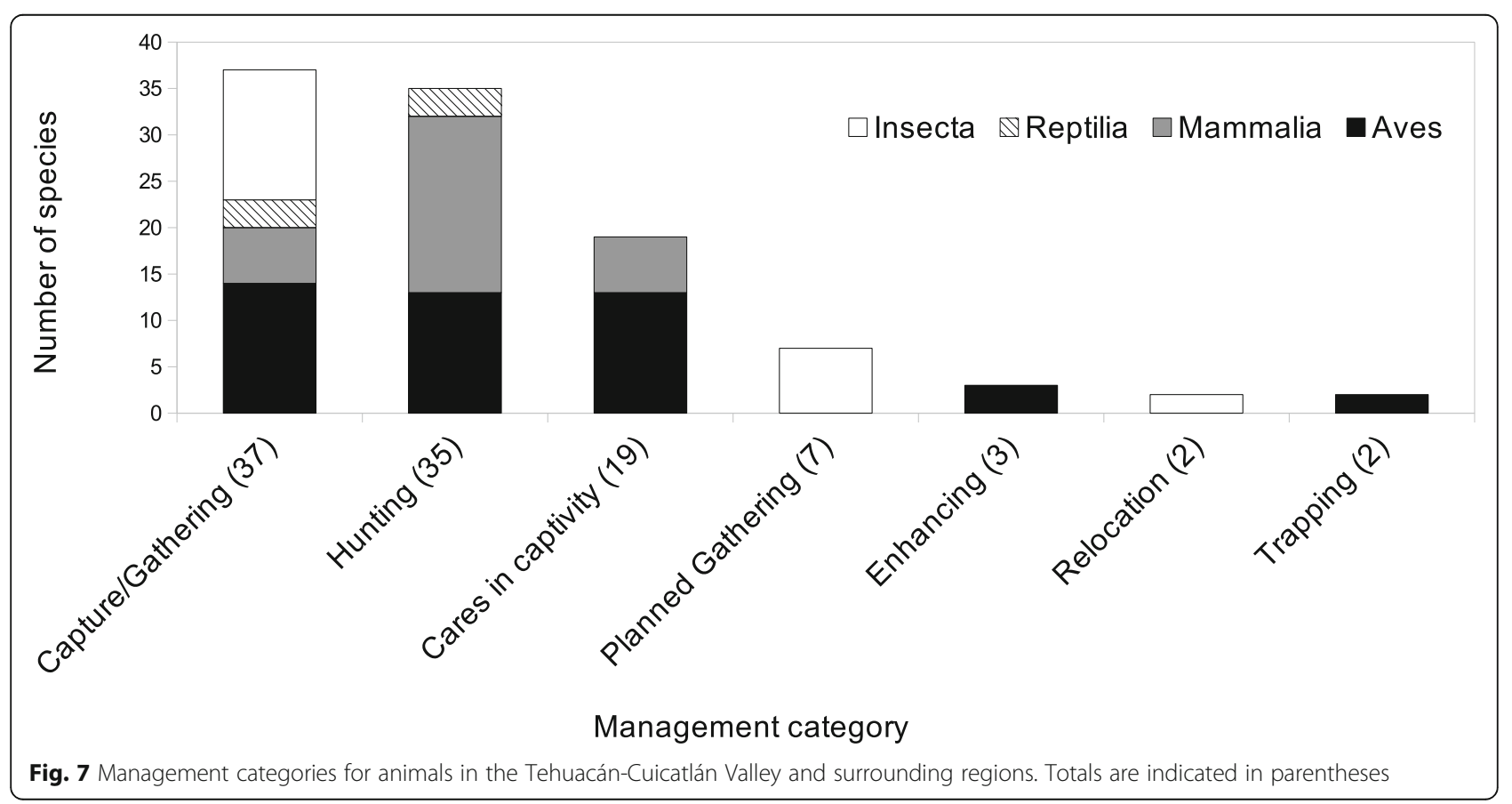




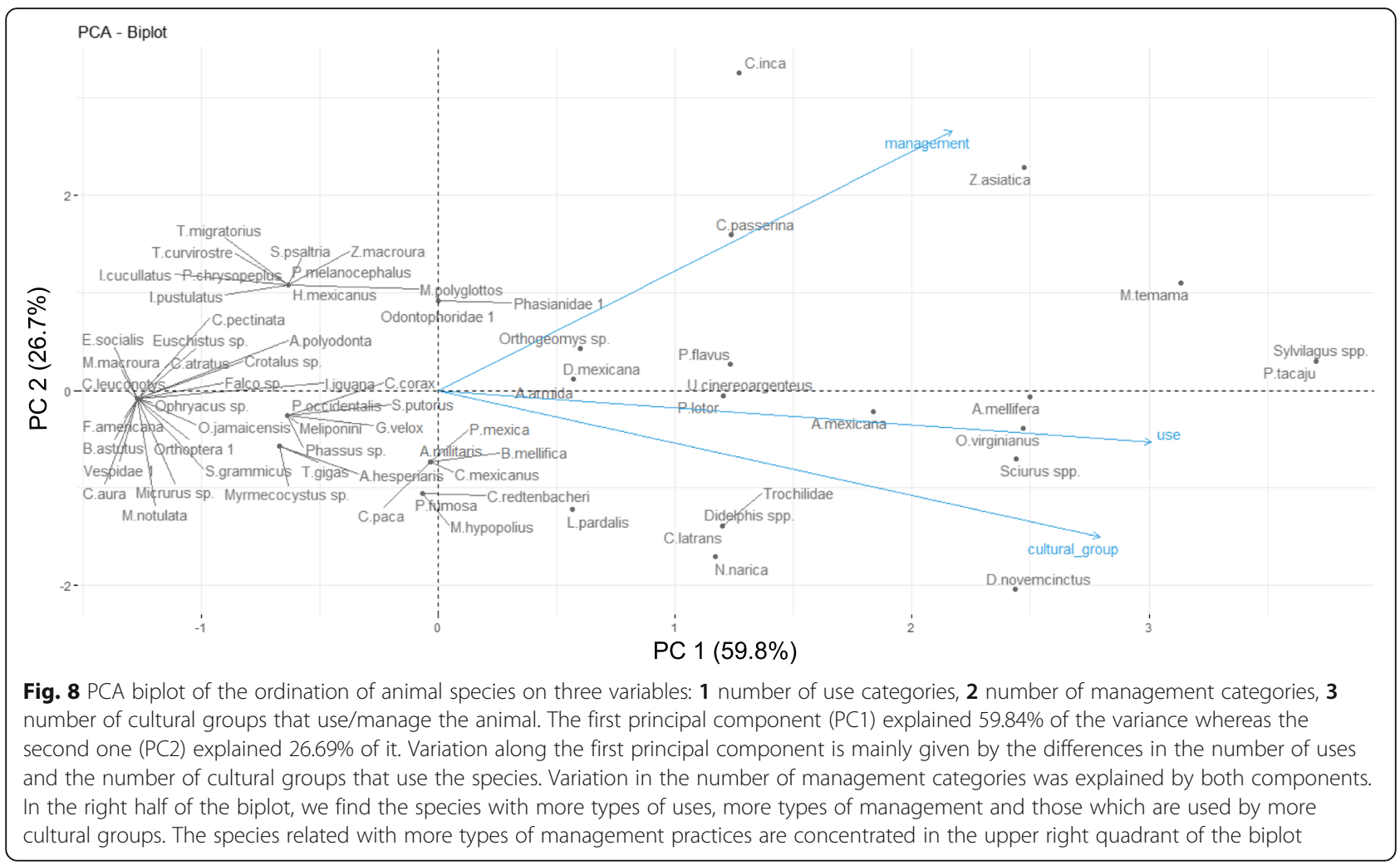

such as D. novemcinctus and Sphiggurus mexicanus (Ker, 1792) are used instead. Didelphis spp. fat is also used in childbirth in the Brazilian Amazon [151], but only to prepare an oil to alleviate labouring women's pain.

We could argue that the study of the use and management of insects is still far from complete in the region, and the numbers do not reflect the general tendency registered for Mexico. We encourage more research on this subject in the area. Yet, a deep perspective of the uses and management of insects was documented in a case study of a Popolocan locality [97]. We also found a case of management of the immature stages of the lepidopteran A. armida in Nahua localities in Coyomeapan, where it is gathered but also receives a kind of in situ management that has been even called a "proto-culture" and has been documented in coffee agroecosystems in the Zongolica region [152]. The extent to which the interest for these caterpillars motivates special cares or management of the host tree $(H$. aff. velutina) beyond tolerance remains to be investigated.

Most of the obtained records of animal use do not include information about frequency and yields of the animals that are extracted, neither about the actual ecosystems from which the extracted animals came from. Contributions in these topics would be valuable together with basic

Table 7 Results of the principal component analysis showing eigenvalues and explained variance for use, cultural group and management of animals

\begin{tabular}{lllll}
\hline Component & Eigenvalue & $\begin{array}{l}\text { Explained variance } \\
(\%)\end{array}$ & Cumulative explained variance (\%) & Scores of variables on the principal component \\
\hline PC1 & 1.79 & 59.84 & 59.84 & $\begin{array}{l}\text { Use: } 0.86 \\
\text { Cultural group: } 0.80 \\
\text { Management: } 0.62\end{array}$ \\
& & & $\begin{array}{l}\text { Use: }-0.15217 \\
\text { Cultural group: }-0.43\end{array}$ \\
PC2 & 26.69 & 86.54 & Management: 0.76 \\
& & & Use: -0.47158 \\
PC3 & 13.45 & 100.00 & & Cultural group: 0.40 \\
& 0.40 & & Management: 0.13
\end{tabular}

avariables are the number of use categories for a given species, number of cultural groups that use a given species and number of management categories for a given species 


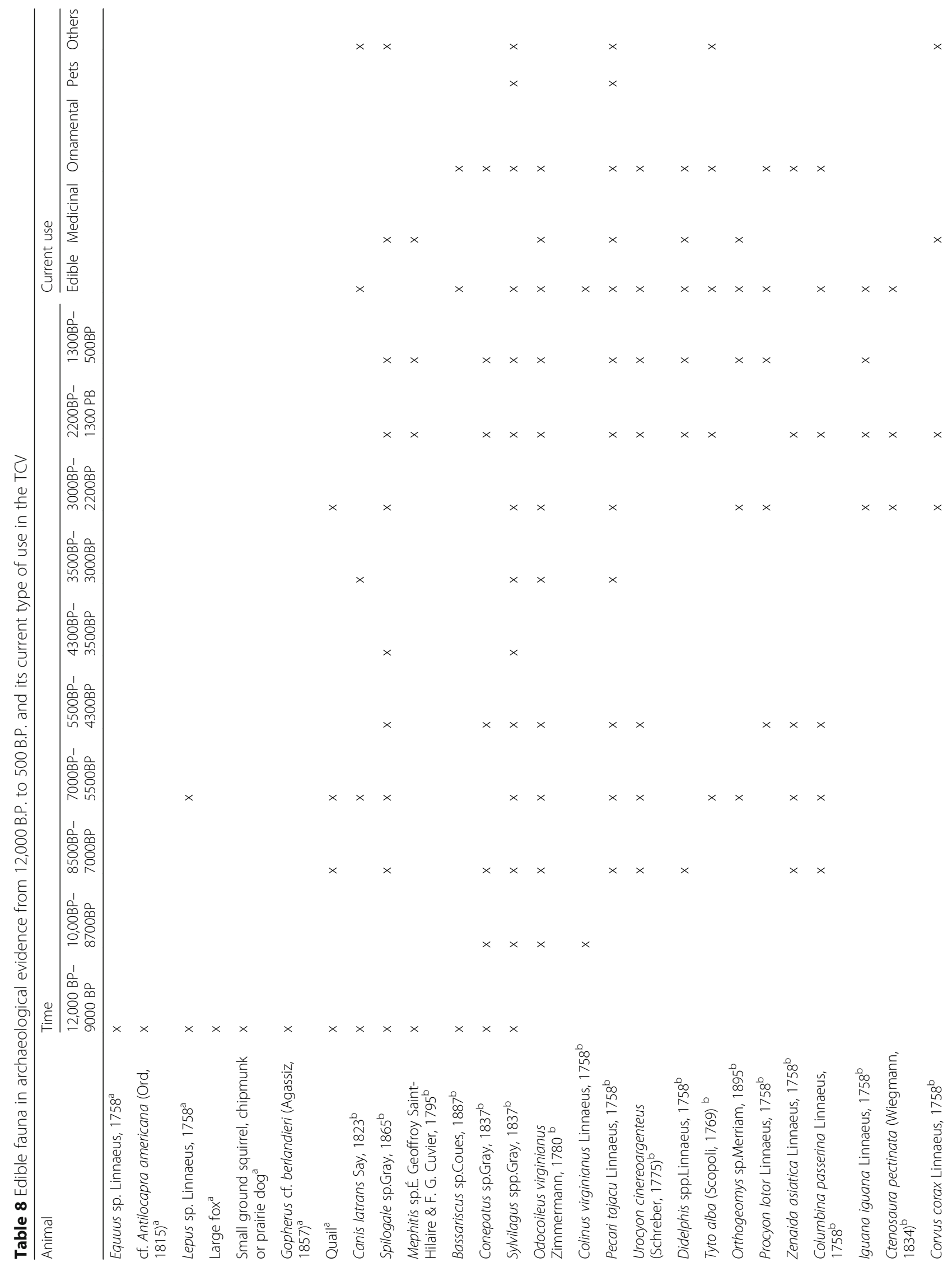




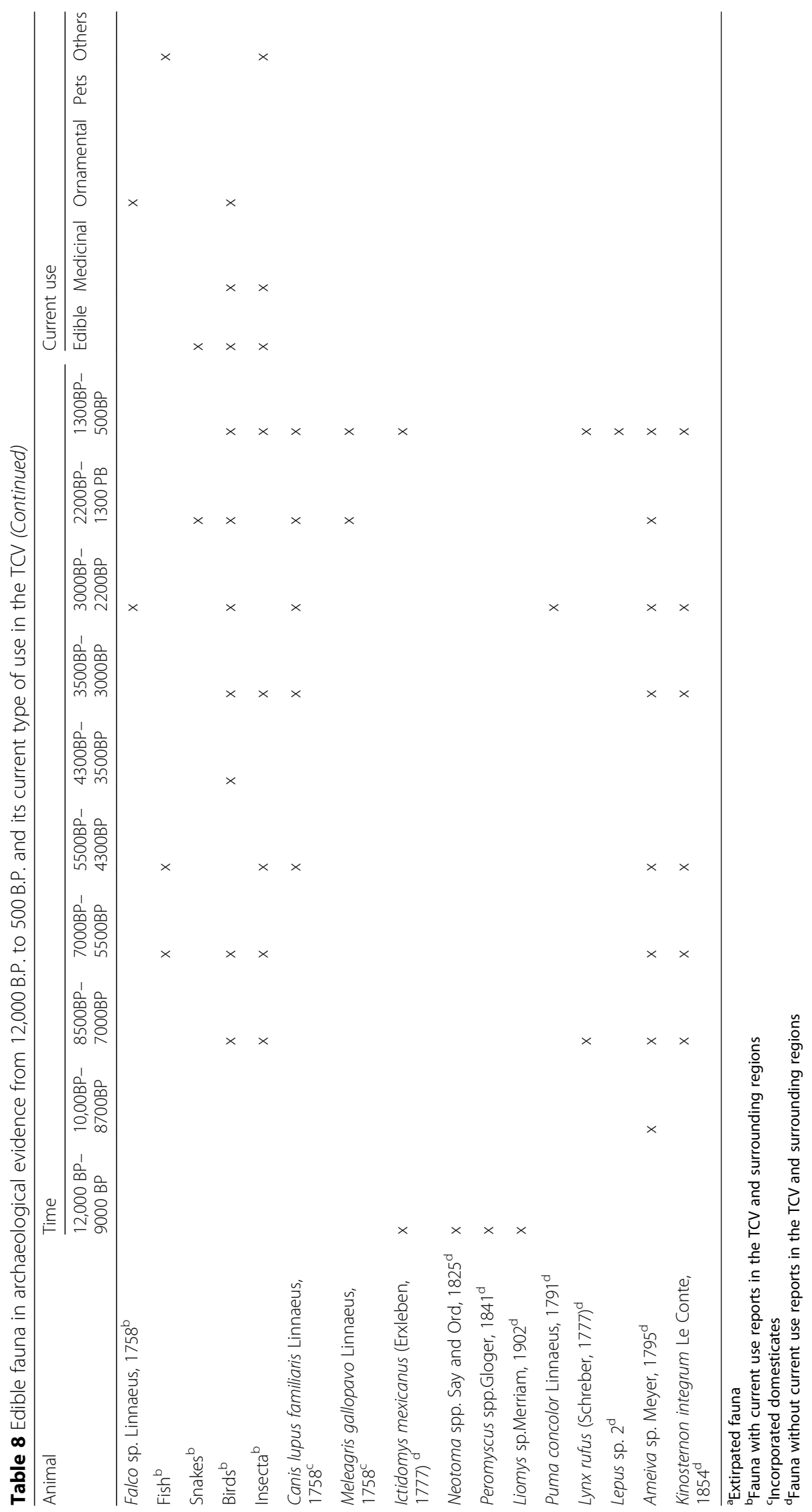


ecological studies since human activity and extractive practices have caused the reduction and almost extirpation of big mammals such as deer and peccaries from some areas of the TCV $[45,47,153]$.

Beyond the tangible-utilitarian attributes reported in the results of this work, the presence of certain animals in an area also may acquire an intangible dimension of use that, in turn, can lead to concrete management actions with positive or negative results for animal survival. For example, fauna which represents bad omens (Catharthes aura (Linnaeus, 1758), Coragyps atratus (Bechstein, 1793), Geococcyx velox (Wagner, 1836), Glaucidium brasilianum (J.F. Gmelin, 1788)) or good fortune (Pyrocephalus rubinus (Boddaert, 1783), Toxostoma curvirostre (Swainson, 1827), Cynanthus sordidus (Gould, 1959)) [72, 98]. This might also be the case of fauna mistakenly considered to be dangerous for human health, as it happens with lizards of the genus Abronia spp. Gray, 1838 Another example is the use of hummingbirds as amulets; this might increase the risk of extirpation since no strategies for maintaining or restoring their populations was recorded. We recommend further research on this topic.

The management typology found so far in the TCV includes a variety of extractive practices similar to those documented in other regions of Mesoamerica. However, we have not found any evidence of breeding as it has been documented for some animals in other regions of Mesoamerica, as it is the case of stingless bees in the Maya region and in the Sierra Norte in Puebla, among others $[15,154]$. We did not find evidence of the manipulation of abiotic elements with the purpose of enhancing the availability of animals [5], nor manipulation at community level with the only purpose of attracting animals as reported in the Maya region [3]. Future research is needed to determine if the documented practices aimed at increasing the availability of the desirable animals are likely to be successful; therefore, we recommend investigating the outcome of these practices.

The use and management of fauna before 1500 B.P. has been discussed in the context of the history of the origins of agriculture in the region [46-48] and involves a transition from seasonal hunting in great human groups to small groups. It might also be related to irrigated cultivation systems by allowing hunters to capture prey attracted to the systems, similar to what happens currently with the milpa. Captivity or breeding of wild animals are not considered to have happened in the region before 1500 B.P., except for D. coccus [155] and the possibly introduced wild M. gallopavo around 2200 B.P. However, Sylvilagus spp. were found in very high proportions compared to other preys and it has been hypothesised that it was due to massive hunting/trapping events [47]. It could be possible that cottontails were captured and maintained in captivity, as it currently happens in some localities of the region, and as it was registered to have possibly happened in Teotihuacan [18].

Up to 2010, there was documentation of 10 animal species found in the archaeological record which are still currently used [153]. Through the review of information carried out in this study, we found reports for 10 additional species which continue to be used, making a total of 20 species. Although in the last 8 years studies on the use and management of regional fauna have increased, we have identified a lack of information on the subject for the Mixtec, Chinantec and Chocholtec communities of the TCV.

Epistemological discussion in ethnobiology and ethnozoology is dynamic [156]. Trends in the thematic of ethnozoological research in Mexico have been reviewed and classified by Brand (1962), Argueta et al. (2012), SantosFita et al. (2012) and Gutiérrez-Santillán et al. (2019) [156$158]$ among others. Works about extractive practices and use of fauna with feeding and ornamental purposes, as well as management issues, specifically domestication or taming, have been present in ethnozoological studies in Mexico. For the TCV, one of the first archaeological studies in which authors discuss these aspects was published in 1967, but the frequency of studies related to management has increased recently. For the period 1890-1962, Brand (1962) identified 4 studies related to hunting and the importance of animals in human diet, 7 studies on domestication and semi-domestication, 15 studies on ornamental use. For the period 1962-2001, Argueta et al. 2012 identified 26 studies on hunting, harvesting, importance in human diet and commercialization, 24 related to use as ornamental, tools, building and dressing elements and 18 studies related to animals in traditional medicine. For the period 2000 to 2011, Santos-Fita et al. 2012 identified 75 studies on hunting, harvesting, diet and commercialization, 16 studies on ornamental use, 30 about animals in traditional medicine and 26 on management and domestication.

A limitation of our work was the lack of analyses on the incorporation of invertebrate and vertebrate domesticates in local systems of subsistence. Further studies on these subjects would complement our understanding of the importance of wild animal resources to fulfil people's needs, as well as the ecological and social processes that might emerge from the management of fauna in the region. An example of work that evaluates the interactions between introduced domesticates in the TCV and vegetation are the studies that have characterised the plant species consumed by goats $[159,160]$ and those that have assessed the effects of goat herbivory on the growth and flower set of plants [161]. Although goats have been considered detrimental for ecosystems, several authors have documented that, at the right densities, these animals may contribute to the conservation of plant diversity and participate in seed dispersal of numerous species [162-164]. Other important issues are the local 
criteria for the human selection of domestic animals. Adaptation to local environments and cultural motivations are important issues to characterise local genetic resources and to complete a history of animal use and management in a region where agriculture and domestication had one of its earliest origins.

\section{Conclusions}

Wild animals are still valuable resources for the inhabitants of the TCV to satisfy mainly edible, ornamental and medicinal needs. To obtain these animals, people in the area perform extractive practices including hunting, gathering and care in captivity among others. Such practices, to our knowledge, do not involve active processes of artificial selection that lead to domestication. However, because of the variation among the strategies involved, we have discussed a typology of extractive practices in the area. Further studies on the qualitative description of these practices, the reasons that have motivated humans to choose them, and the outcome of these practices on animal populations might help us to understand the origins of animal management scenarios and to contribute to biodiversity conservation schemes. It seems to us that ethnozoological information is still lacking in the area since 178 species present in the area without local use reports are used in other regions of Mesoamerica. Besides, ethnozoological information is still not reported among the Mixtec, Chinantec and Chocholtec people of the region.

\section{Supplementary information}

Supplementary information accompanies this paper at https://doi.org/10. 1186/s13002-020-0354-8.

Additional file 1.. VTC localities. Checklist of the localities within the study area.

Additional file 2.. Documentary research conceptual map. Image of a conceptual map in which the documentary research process, including keywords, is summarized.

Additional file 3.. Synthesis of the list of used and managed species in the Tehuacan-Cuicatlan area and surrounding regions used for the analyses. Tabular data with taxonomic information of animals to species level, indicating use and management categories within TCV and its references. Information for each species is summarized in a single line.

Additional file 4.. Records of used and managed species in the Tehuacan-Cuicatlan area and surrounding regions. Tabular data with taxonomic information of animals to species level indicating use and management categories and references.

Additional file 5.. List of animals present in the Tehuacan-Cuicatlan area and surrounding regions, but with use reports in other regions of Mesoamerica. Tabular data with taxonomic information of animals to species level and references. Each line is a species and at least one reference of its presence within the study area in the TCV, and one reference of its use in other regions of Mesoamerica.

\section{Abbreviations}

CIByC: Centro de Investigación en Biodiversidad y Conservación; CONABIO: Comisión Nacional para el Conocimiento y Uso de la
Biodiversidad; CONACYT: Consejo Nacional de Ciencia y Tecnología; DGAPA: Dirección General de Apoyo al Personal Académico; ENES: Escuela Nacional de Estudios Superiores-Morelia; FES-Iztacala: Facultad de Estudios Superiores-Iztacala; GBIF: Global Biodiversity Information Facility; IIES: Instituto de Investigaciones en Ecosistemas y Sustentabilidad; ITIS: Integrated Taxonomic Information System; PAPIIT: Programa de Apoyo a Proyectos de Investigación e Innovación Tecnológica; TCV: Tehuacan-Cuicatlan Valley; UNAM: Universidad Nacional Autónoma de México

\section{Acknowledgements}

The authors thank the Posgrado en Ciencias Biológicas, UNAM, IIES and members of the Laboratorio de Manejo y Evolución de Recursos Genéticos of IIES-UNAM for academic support in the PhD studies of MZC. We also thank CONACYT and DGAPA-UNAM, PAPIIT for their financial support. We especially thank the local authorities and inhabitants of Coyomeapan, Santa María Ixcatlán, Zapotitlán Salinas and San Lorenzo Pápalo for allowing us to conduct part of this research.

\section{Authors' contributions}

MZC and MC performed documentary research and systematized its results. MZC performed data analysis and prepared the first draft of the manuscript. $\mathrm{AC}$ is the main coordinator-supervisor of the research project, contributed to all steps of the research and reviewed several drafts of the manuscript. MZC, MC, YRB, AIM, LFA, SRL, SSA and AC contributed with field data. SSA, MCA, $E V$, JB, SRL, LFA, AIM and AC reviewed the manuscript and contributed to achieve its final version. All authors read and approved the final manuscript.

\section{Funding}

MZC postgraduate studies are being funded through a CONACYT scholarship. Fieldwork was funded by CONACYT (Projects CB-2013-01-221800 and A1-S-14306) and DGAPA-UNAM through the PAPIIT (Projects IN206217 and IN206520).

Availability of data and materials

The datasets used and/or analysed during the current study are available from Additional files 3, 4 and 5.

Ethics approval and consent to participate

Permits for conducting this investigation were obtained from authorities of the localities in Coyomeapan, state of Puebla, and San Lorenzo Pápalo and Santa Maria Ixcatlan, state of Oaxaca. Prior oral consent was obtained from the interviewed people.

Consent for publication

Not applicable.

\section{Competing interests}

The authors declare that they don't have competing interests.

\section{Author details}

${ }^{1}$ Instituto de Investigaciones en Ecosistemas y Sustentabilidad, IIES, Universidad Nacional Autónoma de México, Antigua Carretera a Pátzcuaro 8701, 58190 Morelia, Michoacán, Mexico. ²Escuela Nacional de Estudios Superiores-Morelia, ENES, Universidad Nacional Autónoma de México, Antigua Carretera a Pátzcuaro 8701, 58190 Morelia, Michoacán, Mexico.

${ }^{3}$ Centro de Investigación en Biodiversidad y Conservación, CIByC, Universidad Autónoma del Estado de Morelos, Avenida Universidad 1001. Colonia Chamilpa, 62209 Cuernavaca, Morelos, Mexico. ${ }^{4}$ Facultad de Estudios Superiores-Iztacala, FES-Iztacala, Universidad Nacional Autónoma de México, Avenida de los Baños 1, 54090 Tlalnepantla, Estado de México, Mexico. ${ }^{5}$ Conservación Biológica y Desarrollo Social A.C., CONBIODES A.C., Calle Nueve núm. 52, Int. 4, Colonia Espartaco, Coyoacán, 04870 Ciudad de México, México. ${ }^{6}$ Posgrado en Ciencias Biológicas, Unidad de Posgrado, Universidad Nacional Autónoma de México, Edificio A, $1^{\circ}$ Piso, Circuito de Posgrados, Ciudad Universitaria, Coyoacán, 04510 Ciudad de México, Mexico. 
Received: 21 November 2019 Accepted: 8 January 2020

\section{Published online: 28 January 2020}

\section{References}

1. Nóbrega-Alves R. Relationships between fauna and people and the role of ethnozoology in animal conservation. Ethnobiology and Conservation. 2012;1:2.

2. Zeder M. Core questions in domestication research. Proceedings of the National Academy of Sciences. 2015;112:3191-8.

3. Santos-Fita D, Naranjo E, Bello E, Lugo E, Mariaca R, Macario P. La milpa comedero-trampa como una estrategia de cacería tradicional maya. Estudios de cultura maya. 2013;XLII:87-118.

4. Casas A, Camou A, Otero-Arnaiz A, Rangel-Landa S, Cruse-Sanders J, Solís L, Torres I, Delgado A, Moreno-Calles Al, Vallejo M, Guillén S, Blancas J, Parra F, Farfán-Heredia B, Aguirre-Dugua X, Arellanes Y, Pérez-Negrón E. Manejo tradicional de biodiversidad y ecosistemas en Mesoamérica: el Valle de Tehuacán. Investigación Ambiental. Sección Investigación. 2014; 6(2).

5. Van Itterbeeck J, van Huis A. Environmental manipulation for edible insect procurement. J Ethnobiol Ethnomed. 2012;8:3.

6. Blancas J, Casas A, Pérez-Salicrup D, Caballero J, Vega E. Ecological and sociocultural factors influencing plant management in Náhuatl communities of the Tehuacán Valley, Mexico. J Ethnobiol Ethnomed. 2013;9:39.

7. Berkes F. Sacred Ecology. 2nd ed. New York: Routledge; 2008.

8. Toledo V. Ethnoecology. A conceptual framework for the study of indigenous knowledge of nature. In: Stepp JR, Whyndhan FS, Zarger RK, editors. Ethnobiology and biocultural diversity. Athens: The International Society of Ethnobiology; 2002. p. 511-22.

9. Kirchhoff P. Mesoamérica. Dimensión Antropológica. 2000;19:15-32.

10. Toledo V, Barrera-Bassols N. La memoria biocultural: La importancia ecológica de las sabidurías tradicionales. Icaria: Barcelona; 2008.

11. Harlan JR. Crops and man. American Society of Agronomy. Madison: Crop Science Society of America; 1975.

12. Larson G, Fuller DQ. The evolution of animal domestication. Annual Reviews in Ecology, Evolution and Systematics. 2014;45:115-36.

13. Thornton EK, Emery KF. The uncertain origins of Mesoamerican turkey domestication. Journal of Archaeological Methods and Theory. 2015. https://doi.org/10.1007/s10816-015-9269-4.

14. Chávez-Moreno CK, Tecante A, Casas A. The Opuntia (Cactaceae) and Dactylopius (Hemiptera: Dactylopiidae) in Mexico: a historical perspective of use, interaction and distribution. Biodiversity and Conservation. 2009;18:3337-55.

15. Jones R. Stingless Bees: A historical perspective. In: Roubik D, editor. Vit P, Pedro SRM. Springer: Pot-honey. A legacy of stingless bees. London; 2013. p. 219-28.

16. Minnis E, Whalen ME, Kelley JH, Stewart JD. Prehistoric Macaw Breeding in the North American Southwest. American Antiquity. 1993;58(2):270-6.

17. Somerville AD, Nelson BA, Knudson K. Isotopic investigation of pre-Hispanic macaw breeding in Northwest Mexico. Journal of Anthropological Archaeology. 2010;29:125-35.

18. Somerville AD, Sugiyama N, Manzanilla LR, Shoeninger MJ. Animal management at the ancient metropolis of Teotihuacan, Mexico: Stable isotope analysis of Leporid (Cottontail and Jackrabbit) bonne mineral. PLoS ONE. 2016;11(8):e0159982. https://doi.org/10.1371/journal.pone.0159982.

19. Santos-Fita D, Naranjo E y Rangel-Salazar JL.Wildlife uses and hunting patterns in rural communities of the Yucatan Peninsula, Mexico. Journal of Ethnobiology and Ethnomedicine. 2012; 8:38

20. Mariaca R. Avances en el estudio de la fauna de los traspatios familiares en el sureste de México. In: Casas A, Torres J, Parra F, editors. Domesticación en el continente americano Vol 2, editors. Lima; 2017. p. 475-508.

21. Ramos-Elorduy J. La Etnoentomología actual en México en la alimentación humana, en la medicina tradicional y en el reciclaje y alimentación animal. En: S. Stanford, Morales, A. J. Padilla, M. Ibarra. Memorias del XXXV Congreso Nacional de Entomología. Acapulco; 2000. pp. 3-46.

22. Ramos-Elorduy J, Delage D, Flores R, Sandoval C, Cuevas C. Estructura del nido de Liometopum occidentale var. luctuosum, manejo y cuidado de éstos en los núcleos rurales de México de las especies productoras de escamol (Liometopum apiculatum M., y L. occidentale var. luctuosum W.) (Hymenoptera-Formicidae). Anales del Instituto de Biología, Universidad Nacional Autónoma de México, Ser. Zool. 1986;57(2):333-42.

23. Turok M, Sigler MA, Hernández CE, Acevedo GJ, Lara CR, Turcott V. El caracol púrpura: una tradición milenaria en Oaxaca. Secretaría de Educación Pública, Dirección General de Culturas Populares e Indígenas, Programa de Artesanías y Culturas Populares: Ciudad de México; 1996.
24. Ramos-Elorduy J, Pino-Moreno JM. Los insectos comestibles en el México antiguo. Estudio etnoentomológico. Ciudad de México: A.G.T. Editor; 1989

25. Rangel-Landa S, Casas A, Rivera-Lozoya E, Torres-García V-RM. Ixcatec ethnoecology: plant management and biocultural heritage in Oaxaca, Mexico. Journal of Ethnobiology and Ethnomedicine. 2016;12:30. https://doi. org/10.1186/s13002-016-0101-3.

26. Martínez-Vaca OI, López-Medellín X. Serpientes, un legado ancestral en riesgo. CIENCIA ergo-sum, Revista Científica Multidisciplinaria de Prospectiva; 2019: 26 (2,2). DOI: https://doi.org/10.30878/ces.v26n2a10

27. Romero-Balderas KG, Naranjo E, Morales JHH, Nigh RB. Daños ocasionados por vertebrados silvestres al cultivo de maíz en la Selva Lacandona, Chiapas. México. Interciencia. 2006;31(4):276-83.

28. Rangel-Lada S, Casas A, García-Frapolli E, Lira R. Sociocultural and ecological factors influencing management of edible and non-edible plants: the case of Ixcatlán, México. Journal of Ethnobiology and Ethnomedicine. 2017;13:59. https://doi.org/10.1186/s13002-017-0185-4.

29. Casas A, Otero-Arnaiz A, Pérez-Negrón E, Valiente-Banuet A. In situ management and domestication of plants in Mesoamerica. Annals of Botany. 2007;100:1001-115. https://doi.org/10.1093/aob/mcm126.

30. Torres I, Blancas J, León A, Casas A. TEK, local perceptions of risk, and diversity of management practices of Agave inaequidens in Michoacán. México. Journal of Ethnobiology and Ethnomedicine. 2015;11:61. https://doi. org/10.1186/s13002-015-0043-1.

31. Ramos-Elorduy J, Pino-Moreno JM. Los Coleoptera comestibles de México. Anales del Instituto de Biología, Universidad Nacional Autónoma de México, Serie Zoología. 2004;75(1):149-83 2004.

32. Ramos-Elorduy J, Viejo-Montesinos JL. Los insectos como alimento humano: Breve ensayo sobre la entomofagia, con especial referencia a México. Bol. R. Soc. Esp. Hist. Nat. Sec. Biol. 2007;102(1-4):61-84.

33. Ramos-Elorduy J, Pino-Moreno JM, Vázquez Al, Landero I, Oliva-Rivera H, Camacho VHM. Edible Lepidoptera in Mexico: geographic distribution, ethnicity, economic and nutritional importance for rural people. Journal of Ethnobiology and Ethnomedicine. 2011;7:2 www.ethnobiomed.com/content/7/1/2.

34. Dávila P, Arizmendi MC, Valiente-Banuet A, Villaseñor JL, Casas A, Lira R. Biological diversity in the Tehuacan-Cuicatlan Valley, Mexico. Biodiversity and Conservation. 2002;11:421-42.

35. Granados D, López GF, Hernández-García MA. Valle de Tehuacán y Cañada de Cuicatlán: historia, ecología y agricultura. Chapingo, Edo. De México: Universidad Autónoma Chapingo; 2010.

36. Ávila-Blomberg A, Moreno-Díaz NG. 2008.Distribución de las lenguas indígenas de México. Catálogo de metadatos geográficos. Comisión Nacional para el Conocimiento y Uso de la Biodiversidad. http://www.conabio.gob.mx/ informacion/metadata/gis/lim07gw.xml?_httpcache = yes\&_xsl=/db/ metadata/xsl/fgdc_html.xsl\&_indent = no Accessed 29 October 2019.

37. Cervantes-Zamora Y, Cornejo-Olgín SL, Lucero-Márquez R, EspinozaRodríguez JM, Miranda-Viquez E, Pineda-Velázquez A. 1990. Provincias fisiográficas de México. Catálogo de metadatos geográficos. Comisión Nacional para el Conocimiento y Uso de la Biodiversidad. http://conabio. gob.mx/informacion/metadata/gis/rfisio4mgw.xml?_xsl=/db/metadata/xsl/ fgdc_html.xsl\&_indent = no Accessed 29 October 2019.

38. Open Source Geospatial foundation (OsGeo). Qgis 3.8. Creative commons Attribution-ShareAlike 3.0 license https://www.qgis.org/en/site/about/index. html Accessed 3 January 2020.

39. INEGI 2018. División política municipal. Catálogo de metadatos geográficos. Comisión Nacional para el Conocimiento y Uso de la Biodiversidad http:// www.conabio.gob.mx/informacion/metadata/gis/muni_2018gw.xml?_ httpcache $=$ yes\&_xsl=/db/metadata $/ x s l / f g d c \_h t m l . x s l \& \_i n d e n t=$ no Accessed 25 October 2019.

40. INEGI,CONAGUA 2007. Cuencas hidrográficas de México. Catálogo de metadatos geográficos. Comisión Nacional para el Conocimiento y Uso de la Biodiversidad. http://www.conabio.gob.mx/informacion/metadata/gis/ cue250k_07gw.xml?_xsl=/db/metadata/xsl/fgdc_html.xsl\&_indent = no Accessed 29 October 2019.

41. CONABIO 1998. Curvas de nivel para la República Mexicana. Catálogo de metadatos geográficos. Comisión Nacional para el Conocimiento y Uso de la Biodiversidad. http://www.conabio.gob.mx/informacion/metadata/gis/ cni250kgw.xml?_xsl=/db/metadata/xsl/fgdc_html.xsl\&_indent = no Accessed 31 October 2019

42. Valiente-Banuet A, Casas A, Alcántara A, Dávila P, Flores-Hernández N, Arizmendi MC, Villaseñor JL, Ortega-Ramírez J. La vegetación del Valle de Tehuacán-Cuicatlán. Bol. Soc. Bot. México. 2000;67:24-74. 
43. De la Maza-Elvira R, de Tehuacán-Cuicatlán EV. Biodiversidad y Ecosistemas In: de Tehuacán-Cuicatlán EV, editor. patrimonio natural y cultural. Ciudad de México: Fundación ICA; 2001. p. 21-52.

44. Rzedowski J. Vegetación de México. Ciudad de México: Limusa; 1978.

45. Arizmendi MC, Dávila P. El Valle y su riqueza biológica. In: el Valle de Tehuacán-Cuicatlán: patrimonio natural y cultural. Ciudad de México: Fundación ICA. 2001;2001:72-86.

46. MacNeish R. A summary of the subsistence. In: Byers D, editor. The Prehistory of the Tehuacan Valley Vol I. Environment and Subsistence. San Antonio Texas: University of Arizona Press; 1967. p. 290-310.

47. Flannery K. The vertebrate fauna and hunting patterns. In: Byers D, editor. The Prehistory of the Tehuacan Valley Vol I. Environment and Subsistence. San Antonio Texas: University of Arizona Press; 1967. p. 132-77.

48. Callen. Analysis of the Tehuacan coprolites. In: Byers D, editor. The Prehistory of the Tehuacan Valley Vol I. Environment and Subsistence, vol. 1967. San Antonio Texas: University of Arizona Press; 1967. p. 261-89.

49. Vallejo M, Moreno-Calles A, Casas A. TEK and biodiversity management in agroforestry systems of different socio-ecological contexts of the Tehuacán Valley. Journal of Ethnobiology and Ethnomedicine. 2016;12:31. https://doi. org/10.1186/s13002-016-0102-2.

50. Moreno-Calles Al, Casas A, Rivero-Romero AD, Romero-Bautista YA, RangelLanda S, Fisher-Ortiz RA, Alvarado-Ramos F, Vallejo-Ramos M, Santos-Fita D. Ethnoagroforestry: Integration of biocultural diversity for food sovereignty in Mexico. Journal of Ethnobiology and Ethnomedicine. 2016;12:54. https://doi. org/10.1186/s13002-016-0127-6.

51. Secretaría de Medio Ambiente y Recursos Naturales-Comisión Nacional de Áreas Naturales Protegidas (SEMARNAT-CONANP) 2013. Programa de Manejo de la Reserva de la Biosfera de Tehuacán-Cuicatlán. Ciudad de México; 2013.

52. UNESCO 2019. World Heritage Center. https://whc.unesco.org/en/list/\&order = country\#alphaT, Accessed 6 November 2019.

53. Comisión Nacional para el Conocimiento y Uso de la Biodiversidad (CONABIO) https://www.gob.mx/conabio

54. Canseco L, Gutiérrez M. Anfibios y reptiles del Valle de Tehuacán-Cuicatlán. Ciudad de México: Comisión Nacional para el Conocimiento y Uso de la Biodiversidad. Fundación para la Reserva de la Biosfera Cuicatlán A.C., Benemérita Universidad Autónoma de Puebla; 2010.

55. Global Biodiversity Information Facility GBIF. https://www.gbif.org/es/

56. Briones-Salas M. Lista anotada de los mamíferos de la región de la Cañada, en el Valle de Tehuacán-Cuicatlán, Oaxaca, México. Acta zoologica mexicana (n.s.). 2000:81:83-100.

57. Briones-Salas M, Sánchez-Cordero V. Mamíferos. In: García-Mendoza A., Ordóñez M. de J. y Briones-Salas M., editors. Biodiversidad de Oaxaca. Ciudad de México: Instituto de Biologia Universidad Nacional Autónoma de México, Fondo Oaxaqueño para la Conservación de la Naturaleza World Wildlife Fund; 2004. pp. 423-447.

58. Ramírez-Pulido J. Diversidad de los mamíferos de la Reserva de la biósfera Tehuacán-Cuicatlán, Puebla-Oaxaca, México. Universidad Autónoma Metropolitana-Unidad Iztapalapa. Bases de datos SNIB-CONABIO proyecto No. BK022. Ciudad de México; 2007. https://doi.org/10.15468/dl.kfibqf Accessed 3 Oct 2019.

59. Casas-Andreu G, Méndez-De la Cruz F, Aguilar-Miguel X. Anfibios y Reptiles. In: García-Mendoza A, Ordóñez MJ, Briones-Salas M, editors. Biodiversidad de Oaxaca. Ciudad de México: Instituto de Biologia Universidad Nacional Autónoma de México, Fondo Oaxaqueño para la Conservación de la Naturaleza World Wildlife Fund; 2004. pp. 375-390.

60. Gutiérrez-Mayén, M. G. Herpetofauna de la reserva de la biósfera Valle de Tehuacán-Cuicatlán (etapa final). Benemérita Universidad Autónoma de Puebla. Escuela de Biología. Bases de datos SNIB-CONABIO proyecto No. BK019. Ciudad de México; 2007. https://doi.org/10.15468/dl.5eejwa Accessed 3 Oct 2018

61. Arizmendi MC, Martínez I. Guía de Aves comunes de la Región de la Cañada, Oaxaca, México. Proyecto CONABIO HQ008; 2012. http://www. conabio.gob.mx/institucion/proyectos/resultados/HQ008_Anexo_2.pdf Accessed 2 Feb 2018.

62. CONABIO 2015. AvesMx. Reserva de la biósfera de Tehuacán-Cuicatlán. http:// avesmx.conabio.gob.mx/FichaRegion.htm|\#ANP_134 Accessed on 30 March 2018.

63. Martínez L. 2013. Estudio lepidopterofaunístico en la Reserva de la Biosfera Tehuacán-Cuicatlán, Oaxaca-Puebla. Universidad Nacional Autónoma de México. Facultad de Ciencias. Base de datos SNIB-CONABIO proyecto No. BK062, V010, T025, R256, M099, J123 Mariposas, J083, H210, H209, B150, P065, P063, A025. México, D. F.
64. Vergara-Briceño $\mathrm{CH}$, Comisión nacional para el conocimiento y uso de la biodiversidad C. Actualización de la base de datos del proyecto H278 Apoidea (Hymenoptera) del Valle de Zapotitlán de las Salinas, Puebla. Comisión nacional para el conocimiento y uso de la biodiversidad; 2018. https://doi.org/10.15468/wv3xpz Accessed on 22 Jan 2019.

65. Vergara C, Ayala R. Diversity, phenology and biogeography of the bees, (Hymenoptera: Apoidea) of Zapotitlan de las Salinas, Puebla, Mexico. Journal of the Kansas Entomological Society. 2002;75(1):16-30.

66. Ríos-Casanova L, Valiente-Banuet A, Rico-Gray V. Las hormigas del Valle de Tehuacán (Hymenoptera:Formicidae): una comparación con otras zonas áridas de México. Acta Zoológica Mexicana (nueva serie). 2004;001:37-54.

67. Morón-Ríos MA, Comisión nacional para el conocimiento y uso de la biodiversidad. Diversidad de coleópteros scarabaeoidea del estado de Puebla (I). Comisión nacional para el conocimiento y uso de la biodiversidad;2018. https://doi.org/10.15468/m5pubu Accessed on 5 Feb 2019.

68. Aragón-García A. Diversidad de los coleópteros Scarabaeiodea del estado de Puebla (II). Benemérita Universidad Autónoma de Puebla. Instituto de Ciencias. Bases de datos SNIB-CONABIO proyecto No. R024. México, D.F; 2001. http://www.conabio.gob.mx/institucion/cgi-bin/datos2.cgi?Letras= R\&Numero=24 Accessed on 5 Feb 2019.

69. Brailovsky H, Barrera E, Mayorga C, Ortega-León G. Estadios ninfales de los coreidos del Valle de Tehuacan-Puebla (Hemiptera-Heteroptera). I. Chelinidea Staffilesi, C. tabulata y Narnia femorata. Anales del Instituto de Biologia. UNAM. Serie Zoologia. 1994;65(2):241-64.

70. Cano-Santana Z, Castellanos-Vargas I. Ortopteroides de Oaxaca, México: Orthoptera, Mantodea y Phasmatodea. Universidad Nacional Autónoma de México. Facultad de Ciencias. Bases de datos SNIB-CONABIO, proyecto GE001. México, D.F.; 2012. http://www.conabio.gob.mx/institucion/cgi-bin/ datos2.cgi? Letras=GE\&Numero=1 Accessed on 5 Feb 2019.

71. Jongema Y. 2014. List of edible insects of the world. Wageningen University, Wageningen, the Netherlands. https://www.wur.nl/en/Research-Results/ Chair-group/Plant-Sciences/Laboratory-of-Entomology/Edible-insects/ Worldwide-species-list.htm Accessed 30 Apr 2018.

72. Solís L, Casas A. Cuicatec ethnozoology: traditional knowledge, use and management of fauna by people of San Lorenzo Pápalo, Oaxaca. Mexico. Journal of Ethnobiology and Ethnomedicine. 2019;15:58.

73. Romero-Bautista Y. Los saberes de las zonas semiáridas: interacciones ambientales entre las aves y los pobladores de Zapotitlán Salinas, Puebla, México. Tesis de Licenciatura en Ciencias Ambientales: Escuela Nacional de Estudios Superiores Unidad Morelia. Universidad Nacional Autónoma de México; 2019.

74. Botello F, Illoldi P, Linaje M, Monroy G, Sánchez-Cordero V. Nuevos registros del tepezcuintle (Agouti paca), para el norte del estado de Oaxaca. México. Revista Mexicana de Biodiversidad. 2005;76:103-5.

75. Botello F, Illoldi-Rangel P, Linaje M, Sánchez-Cordero V. Primer registro del tigrillo (Leopardus wiedii, Schinz 1821) y del gato montés (Lynx rufus, Kerr 1792) en la Reserva de la Biosfera de Tehuacán-Cuicatlán, Oaxaca, México. Acta zoológica mexicana. 2006;22(1):135-9.

76. Botello F, Salazar JM, Illoldi-Rangel P, Linaje M, Monroy G, Duque D, Sánchez-Cordero V. Primer registro de la nutria neotropical de río (Lontra longicaudis) en la Reserva de la Biosfera de Tehuacán-Cuicatlán, Oaxaca, México. Revista mexicana de biodiversidad. 2006;77(1):133-5.

77. Botello F, Villaseñor E, Guevara L, Méndez A, Cortés A, Iglesias J, Izúcar M, Luna M, Martinez A, Salazar J. Registros notables del zorrillo manchado (Spilogale angustifrons) y del jaguarundi (Puma yagouaroundi) en la Reserva de la Biosfera de Tehuacán-Cuicatlán, Oaxaca. México. Revista Mexicana de Biodiversidad. 2013;84:713-7.

78. Cruz-Jacome O, López-Tello E, Delfín-Alfonso CA, Mandujano S. Riqueza y abundancia relativa de mamíferos medianos y grandes en una localidad en la Reserva de la Biosfera Tehuacán-Cuicatlán, Oaxaca. México. THERYA. 2015; 6(12):435-48.

79. Espinosa-Lucas A, Méndez A, Hernández O, Flores-Cortes A, Botello F, Mariscal I. Tres nuevos registros en la zona de influencia de la Reserva de la Biósfera Tehuacán-Cuicatlán. Oaxaca. THERYA. 2015;6(3):661-6.

80. Pérez-Solano L, Mandujano S, Contreras-Moreno F, Salazar JM. Primeros registros del temazate rojo Mazama temama en áreas aledañas a la Reserva de la Biosfera de Tehuacán-Cuicatlan Mexico. Revista Mexicana de Biodiversidad. 2012;83:875-8.

81. Briones-Salas M, Lavariega M, Lira-Torres I. Distribución actual y potencial del jaguar (Panthera onca) en Oaxaca. México. Revista Mexicana de Biodiversidad. 2012;83:246-57. 
82. García-Vázquez UO, Canseco-Márquez L, Aguilar-López JL. Zootaxa. 2010; 2657:47-54.

83. Luría-Manzano R, Canseco-Márquez L, Frías-Álvarez P. Herpetological Reviews. 2011;4(4):552-3.

84. Luría-Manzano R, Aguilar-López JL, Canseco-Márquez L, Gutiérrez-Mayén MG. Distribución geográfica de Anotheca spinosa (Anura: Hylidae) en México: nuevo registro para la anfibiofauna de Puebla. Revista mexicana de biodiversidad. 2014;85(4):1285-8.

85. Luría-Manzano R, Ramírez-Bautista A, Canseco-Márquez L. Rediscovery of the Rare Snake Rhadinaea cuneata Myers, 1974 (Serpentes: Colubridae: Dipsadinae). Journal of Herpetology. 2014;48(1):122-4.

86. Melgarejo-Vélez E, Chávez-Ortiz M, Luría-Manzano R, Aportela-Cortés D, Galicia-Portano DM, Canseco-Márquez L, Gutiérrez-Mayen G. Ampliación del área de distribución de la rana Hyalinobatrachium fleischmanni (Anura: Centrolenidae) en el estado de Puebla y del límite septentrional de su distribución. Acta zoológica mexicana. 2010;26(2):473-6.

87. Luría R. Ecología trófica del ensamble de anuros riparios de San Sebastián Tlacotepec, Sierra Negra de Puebla, México. Tesis de Maestría: Universidad Autónoma del Estado de Hidalgo; 2012.

88. Arizmendi M.C y Valiente-Banuet A. Aves de la Reserva de la Biosfera Tehuacán-Cuicatlán. Ciudad de México: Universidad Nacional Autónoma de México, Comisión nacional para el conocimiento y uso de la biodiversidad, Fundación para la reserva de la biósfera Tehuacán-Cuicatlán; 2006.

89. Camacho-Morales, M., 2001. Monitoreo de las aves silvestres en zona prioritaria de Zapotitlán-Salinas, Puebla. Unión de Capturadores, transportistas y vendedores de aves canoras y de ornamento del estado de Puebla AC. Bases de datos SNIB-CONABIO, proyecto No. R121. Ciudad de México. http://www.conabio.gob.mx/institucion/cgi-bin/datos.cgi?Letras= R\&Numero=121 Accessed on 5 Mar 2019.

90. González-García F, Pérez-Solano LA, Ramírez-Bravo OE, Mandujano S, Ramírez-Julián R, Reyes Macedo G, Salazar-Torres JM, Guillén-Servent A. Localidades adicionales en la distribución geográfica de la pava cojolita (Penelope purpurascens) en Puebla y Oaxaca, México. HUITZIL. 2012;13(1): 61-67. http://www.scielo.org.mx/scielo.php?script=sci_arttext\&pid=S187074592012000100010\&lng=es\&nrm=iso. Accessed 14 Jan 2020.

91. Arizmendi MC y Espinosa M. Avifauna de los Bosques de Cactáeas Columnares del Valle de Tehuacán, Puebla. Acta Zoológica Mexicana nueva serie. 1996; 67: 25-46.

92. Rojas-Soto O, Navarro A. Información reciente sobre la avifauna del estado de Puebla. Anuales del Instituto de Biología. UNAM, Serie zoología. 1999; 70(2):205-13.

93. Vázquez L, Vázquez-Reyes JA, Arizmendi MC. Registro del gavilán pescador (Pandion haliaetus) en el valle de Tehuacán-Cuicatlán, norte de Oaxaca. HUITZIL. 2009;10(1):24-6.

94. Martínez-Ramírez E, Cruz-Arenas E, Cruz-Ruiz Gl, Gómez-Ugalde RM. Los Peces de la Reserva de la Biosfera Tehuacán-Cuicatlán, Región Oaxaca. In: Briones-Salas M, Manzanero-Medina G, González-Pérez G, editors. Estudios en zonas Áridas de Oaxaca. Homenaje al Dr. Alejandro Flores Martínez. Oaxaca: Centro Interdisciplinario de Investigación para el Desarrollo Integral Regional, Unidad Oaxaca del Instituto Politécnico Nacional (CIIDIR-IPN Unidad Oaxaca); 2013. pp.130-144.

95. Arnold N, Ayala R, Mérida J, Sagot P, Aldasoro M, Vandame R. Registros nuevos de abejas sin aguijón (Apidae: Meliponini) para los estados de Chiapas y Oaxaca. México. Revista Mexicana de Biodiversidad. 2018;89:651-65.

96. Ramos-Elorduy J, Pino-Moreno JM, Escamilla E, Alvarado M, Lagunez J, Ladrón de Guevara O. Nutritional value of edible insects from the state of Oaxaca, México. Journal of Food Composition and Analysis. 1997; 10: 142-158.

97. Acuña A, Caso L, Aliphat MM, Vergara C. Edible insects as part of the traditional food system of the Popoloca town of Los Reyes Metzontla. México. Journal of Ethnobiology. 2011;31(1):150-69.

98. Rangel-Landa S, Smith-Aguilar SE, Rivera-Lozoya E, Swanton M, Casas A, Solís L, Pérez A, Villaseñor C. Patrimonio biocultural ixcateco. Ciudad de México: Universidad Nacional Autónoma de México; 2016.

99. Avendaño A, Casas A, Dávila P, Lira R. Use forms, management and commercialization of "pochote" Ceiba aesculifolia (H.B. y K.) Britten \& Baker f. subsp. parvifolia (Rose) P.E. Gibbs \& Semir (Bombacacee) in the Tehuacan Valley, Central Mexico. Journal of Arid Environments. 2006;67:15-35.

100. Ávila-Cortés LG. Cumplir con el rito según el costumbre: Las prácticas culturales de los rituales funerarios entre los nahuas de Xaltepec de la Sierra Negra de Puebla. Tesis de Maestría. Posgrado en Antropología UNAM; 2013.
101. Galindo A, Rosas C, Vázquez V, Alcántara J, Bravo G. Uso de mamíferos silvestres por nahuas y mazatecos. CONABIO. Biodiversitas. 2010;134:6-11.

102. Garzón-Macip G. 2016. Chajchammas: agua, puntas y paciencia. X. Congreso Mexicano de Etnobiología. 19-23 de septiembre de 2016.

103. Ramos-Elorduy J, Pino-Moreno M. y Romero. Determinación del valor nutritivo de algunas especies de algunas especies de insectos comestibles del estado de Puebla. Anales del Instituto de Biología UNAM Serie Zoología. 1988;58(1):355-72

104. Reyes V. Representaciones culturales (conocimiento, cosmos y aprovechamiento) de los mamíferos silvestres en Cerro Mirador y San Mateo Yetla, Oaxaca. Tesis de Licenciatura: Universidad Nacional Autónoma de México; 2010.

105. Solano-Hernández L. Importancia ecológica y cultural de los recursos vegetales de Asunción Cuyotepeji, Oaxaca, México. Instituto Politécnico Nacional: Tesis de Maestría; 2009.

106. Vallejo M, Casas A, Moreno A, Blancas J. Los sistemas agroforestales del Valle de Tehuacán: una perspectiva regional. In: Moreno A, Toledo V, Casas A, Vallejo M, eds.. Etnoagroforesteria en Mexico; 2016. pp. 194-216

107. Roldán-Clarà B, Toledo V, Espejel I. The use of birds as pets in Mexico. Journal of Ethnobiology and Ethnomedicine. 2017;13:35.

108. Alarcón-Chaires P. Flora, Fauna y apropiación de la naturaleza en la región nahua de Michoacán. Proyecto de conservación de la biodiversidad en comunidades indígenas de los estados de Oaxaca, Michoacán y Guerrero, CIECO UNAM, Comunidad Indígena El Coire: COINBIO; 2005.

109. Ávila-Nájera DM, Mendoza GD, Villareal O, Serna-Lagunes R. Uso y valor cultural de la Herpetofauna en México: Una revisión de las últimas dos décadas (19972017). Acta Zoológica Mexicana Nueva Serie. 2018; Vol 34: 1-15.

110. Barragán F, Retana OG, Naranjo EJ. The rodent trade of Tzeltal indians of Oxchuc, Chiapas. Mexico. Human Ecology. 2007;35(6):769-73.

111. Buenrostro A, Rodríguez de la Torre M, García-Grajales J. Uso y conocimiento tradicional de la fauna silvestre en el Parque Nacional Lagunas de Chacahua, Oaxaca. Revista Quehacer Científico en Chiapas; 2016: 11 (1)

112. Contreras-Díaz RG, Pérez-Lustre M. Etnoecología de mamíferos silvestres y los zapotecos del municipio de Santiago Camotlán, Villa Alta. Oaxaca. Etnobiología. 2015;6(1):56-67.

113. Contreras-Moreno FM, De la Cruz-Félix K, Bello-Gutiérrez J. Uso Patrones de Cacería y Preferencia de Presas en Dos Sitios del Parque Estatal la Sierra, Tabasco. México. Etnobiología. 2015;10(3):1-9.

114. Corona E. A la búsqueda de tendencias históricas en el consumo de vertebrados en Chiapas (México). Un estudio de caso combinando evidencias/In Search of Historical Trends on Vertebrate Consumption in Chiapas (Mexico). A Study Case Combining Evidences. Revista Española de Antropología Americana. 2012;42(1):29-43.

115. Cossío A, Gonzalez A, Sosa V, Nigh R. Diagnóstico de la organización comunitaria para el uso de fauna silvestre en dos comunidades ejidales del municipio de Hueytamalco, Puebla, México. In: Uso y manejo de fauna silvestre en el norte de Mesoamérica. Gallina, S., Naranjo, J., Guerra-Roa, M. y Calmé S, Editors. Xalapa: Secretaría de Educación del Gobierno del Estado de Veracruz; 2010.

116. De María y Campos T. Los animales en la medicina tradicional mesoamericana. Anales de Antropología 1979; Vol. 16. http://www.revistas.unam.mx/index.php/ antropologia/article/view/24188/pdf_871 Accessed 22 Oct 2019.

117. Cruz Jacinto MA, Vásquez-Dávila MA, Colunga GMP, Jerez Salas MP. Aspectos etnoecológicos de la ornitofauna entre los ikoot de San Mateo del Mar, Oaxaca, México. In: Vásquez-Dávila MA, editor. Aves, personas y culturas. Estudios de Etno-ornitología 1. Oaxaca, Mexico: CONACYT/TTVO/ Carteles Editores/UTCH; 2014. pp. 151-167.

118. De la Cruz Montesino F, Vásquez-Dávila MA, Jerez Salas MP, MontañoContreras EA, Villegas A. Aves silvestres y domésticas de los chontales de San Andrés Tlahuilotepec, Distrito de Yautepec, Oaxaca, México. In: Vásquez-Dávila MA, editor. Aves, personas y culturas. Estudios de Etnoornitología 1. Oaxaca, México: CONACYT/TVO/Carteles Editores/UTCH; 2014. pp. 169-186.

119. Escalante-Vargas M, Trejo-Pérez JL. Aves silvestres criadas en cautiverio en Huapacal Segunda Sección, Jalpa de Méndez, Tabasco, México. In: VásquezDávila MA, editor. Aves, personas y culturas. Estudios de Etno-ornitología 1. Oaxaca, Mexico: CONACYT/TVO/Carteles Editores/UTCH; 2014. pp. 59-69.

120. García SB. Conocimiento y usos tradicionales de la fauna en dos comunidades campesinas de la Reserva de Biosfera de la Encrucijada. Chiapas. Etnobiología. 2015;11(1):16-28. 
121. García-Flores A, Lozano-García MA, Ortiz-Villaseñor AL, Monroy-Martínez R. Uso de mamíferos silvestres por habitantes del Parque Nacional El Tepozteco, Morelos. México. Etnobiología. 2015;12(3):57-67.

122. García-Flores A, Valle R, Monroy-Martínez R. Aprovechamiento tradicional de mamíferos silvestres en Pitzotlán, Morelos. México. Revista Colombiana de Ciencia Animal-RECIA. 2018:111-23.

123. Gil RA, Guiascón OG. Uso de la Fauna Silvestre en la Comunidad Maya Villa De Guadalupe, Campeche. México. Etnobiología. 2015;10(2):1-11.

124. Gomez B, Castro A, Junghans C, Ruiz-Montoya L, Villalobos FJ. Ethnoecology of white grubs (Coleoptera:Melolonthidae) among the Tzeltal Maya of Chiapas. Journal of Elhnobiology. 2000;20(1):43-59.

125. González-Romo CE, Garza Torres HA, Padrón-Serrano E, Jiménez-Ramírez R, Berrones-Benítez E. Las aves de El Cielo: Etnobiología y observación de la naturaleza para su conservación en un área natural protegida de Tamaulipas, México. In: Vásquez-Dávila MA, editor. Aves, personas y culturas. Estudios de Etno-ornitología 1. Oaxaca, Mexico: CONACYT/ITVO/ Carteles Editores/UTCH; 2014. pp. 261-283.

126. Guerrero-Sánchez S, Cano-Contreras EJ, Mariaca R, Guerrero-Martínez R. Conocimiento local sobre el manejo sanitario de aves de traspatio en dos grupos mayenses del sureste de México. In: Vásquez-Dávila MA, editor. Aves, personas y culturas. Estudios de Etno-ornitología 1. Oaxaca, México: CONACYT/ITVO/Carteles Editores/UTCH; 2014. pp. 71-81.

127. Jaimes-Yescas MI, Gómez-Álvarez G, Pacheco-Coronel N, Reyes Gómez SR. Uso y manejo de la avifauna en San Miguel Tzinacapan, municipio de Cuetzalan del Progreso, Puebla, México. In: Vásquez-Dávila MA, editor. Aves, personas y culturas. Estudios de Etno-ornitología 1. Oaxaca, México: CONACYT/ITVO/Carteles Editores/UTCH; 2014. pp. 243-259.

128. Jiménez-Díaz JE, Vásquez-Dávila MA, Naranjo E, Jerez-Salas MP. Las relaciones humano-aves en Lacanjá-Chansayab, Selva Lacandona, Chiapas, México. In: Vásquez-Dávila MA, editor. Aves, personas y culturas. Estudios de Etno-ornitología 1. Oaxaca, México: CONACYT/ITVO/Carteles Editores/ UTCH; 2014. pp. 83-106.

129. Lorenzo MC, Cruz L, Naranjo E, Barragán F. Uso y conservación de mamíferos silvestres en una comunidad de las cañadas de la Selva Lacandona, Chiapas. México. Etnobiología. 2007;5:99-107.

130. López E, Gómez-y-Gómez B, Sánchez-Cortés MS, Junghans C, y MartínezJiménez LV. Insectos útiles entre los tsotsiles del municipio de San Andrés Larráinzar, Chiapas, México. Etnobiología. 2015; 13 (2):72-84.

131. Monroy R, García-Flores A. La fauna silvestre con valor de uso en los huertos frutícolas tradicionales de la comunidad indígena de Xoxocotla, Morelos. México. Etnobiología. 2015;11(1):44-52.

132. Naranjo E, Guerra M, Bodmer RE, Bolaños JE. Subsistence hunting by three ethnic groups of the Lacandon Forest. Mexico. Journal of Ethnobiology. 2004:24:233-53.

133. Ortiz SG, Retana-Guiascón OG. Nota Científica: Uso Medicinal de la Fauna Silvestre por Indígenas Tlahuicas en Ocuilan. México. Etnobiología. 2015; 10(3):28-33.

134. Retana-Guiascón, OG., Puc-Gil RA, Martínez-Pech LG. Uso de la fauna silvestre por comunidades mayas de Campeche, México: El caso de las aves. In: Vásquez-Dávila MA, editor. Aves, personas y culturas. Estudios de Etnoornitología 1. Oaxaca, Mexico: CONACYT/ITVO/Carteles Editores/UTCH; 2014 pp. 35-46.

135. Reyna-Rojas MA, García A, Neri E, Alagón A, Monroy R. Conocimiento etnoherpetológico de dos comunidades aledañas a la Reserva Estatal Sierra de Montenegro, Morelos. México. Etnobiologia. 2015;13(2):37-48.

136. Rodas-Trejo J, Estrada A, Acuña JR, Morales-Hernández M. Uso local de los mamíferos no voladores entre los habitantes de Metzabok, El Tumbo y Laguna Colorada, Selva Lacandona. México. Etnobiología. 2016;14(1):39-50.

137. Serrano-González R, Guerrero-Martínez F, Pichardo-Barreiro Y, SerranoVelázquez R. Los Artrópodos Medicinales en tres fuentes Novohispanas del Siglo XVI. Etnobiologia. 2013;11(2):24-34.

138. Vargas Z. Valoración de los vertebrados terrestres por huaves y zapotecas del Istmo de Tehuantepec, Oaxaca, México. El Colegio de la Frontera Sur. San Cristóbal de Las Casas, Chiapas, México: Tesis de Maestría; 2001.

139. Vásquez-Cruz R, Vásquez-Dávila MA, Montaño-Contreras EA, Jerez Salas MP. Ornitología zapoteca de San José Quianitas, Sierra Sur de Oaxaca, México. In: Vásquez-Dávila MA, editor. Aves, personas y culturas. Estudios de Etnoornitología 1. Oaxaca, México: CONACYT/ITVO/Carteles Editores/UTCH; 2014. pp. 187-205

140. Zavala-Sánchez Z, Segura-Pacheco H, Ávila-Nájera DM, Herrera-Castro ND, Barrera-Catalán E, Sarabia-Ruiz G. Valoración cultural y uso de la fauna silvestre en San Vicente de Benítez, Guerrero, México. 2018; Etnobiología 16 (3): 78-92

141. Ramos-Elorduy J. Threatened edible insects in Hidalgo. Mexico and some measures to preserve them. Journal of Ethnobiology and Ethnomedicine. 2006;2:51. https://doi.org/10.1186/1746-4269-2-61.

142. Ramos-Elorduy J, Pino-Moreno M. El consumo de Insectos entre los lacandones de la comunidad Bethel y su valor nutritivo. Etnobiologia. 2001;1:24-43.

143. Monroy R, Pino M, Lozano M, García-Flores A. Estudio etnomastozoologico en el corredor biológico Chichinautzin (COBIO), Morelos. México. Sitientibus. Série Ciencias Biologicas. 2011;11(1):16-23.

144. Integrated Taxonomic Information System (ITIS) 2019 and 2000 (http:// www.tis.gov). Lastly accessed 26 Dec 2019.

145. Silva VA da, Nascimento VT do, Soldati GT, Medeiros MFT, Albuquerque UP. Techniques for Analysis of Quantitative Ethnobiological Data: Use of Indices. In: Albuquerque UP, Cruz da Cunha LVF, Lucena RFP, Nóbrega Alves RR, editors. Methods and Techniques in Ethnobiology and Ethnoecology. Springer Protocols Handbooks DOl: 10.1007/978-1-4614-8636-7_24. 2014; pp. $381-398$.

146. Kassambara A. and Mundt F. Factoextra package for R Development Core Team; 2017. https://cran.r-project.org/web/packages/factoextra/factoextra. pdf Accessed 22 Aug 2019.

147. Development Core Team R. R: A language and environment for statistical computing. Vienna, Austria: R Foundation for Statistical Computing; 2019. http://www.R-project.org/

148. Roldán-Clarà B, López-Medellín X, Espejel I, Arellano E. Literature review of the use of birds as pets in Latin-America, with a detailed perspective on Mexico. Ethnobiology and Conservation. 2014; 3:5 DOl: 10.15451/ec2014-10-3.5-1-18.

149. Alves RRN, Alves HN. The faunal drugstore: Animal-based remedies used in traditional medicines in Latin America. Journal of Ethnobiology and Ethnomedicine. 2011;7:9

150. Santos-Fita D, Costa-Neto E, Schiavetti A. Offensive snakes: cultural beliefs and practices related to snakebites in a Brazilian rural settlement. Journal of Ethnobiology and Ethnomedicine. 2010;6:13.

151. Barros FB, de Aguiar PA. Common opossum (Didelphis marsupialis Linnaeus, 1758): food and medicine for people in the Amazon. Journal of Ethnobiology and Ethnomedicine. 2014;10:65.

152. Escamilla-Prado E, Escamilla-Femat S, Gómez-Utrilla JM, Tuxtla-Andrade M, Ramos-Elorduy J, Pino-Moreno JM. Uso tradicional de tres especies de insectos comestibles en agroecosistemas cafetaleros del estado de Veracruz. Tropical and Subtropical Agroecosystems. 2012;15(2):S101-9.

153. Casas A, Valiente-Banuet A, Pérez-Negrón E, Solís L. El manejo de la biodiversidad en el desierto: el Valle de Tehuacán-Cuicatlán. In: Toledo V, editor, La Biodiversidad de México. Inventarios, manejos, usos, informática, conservación e importancia cultural. Fondo de Cultura Económica, Consejo Nacional para la cultura y las artes. Ciudad de México. 2010; pp. 235-272.

154. Ayala R, González V, Engel M. Mexican Stingless Bees (Hymenoptera: Apidae): Diversity, distribution and indigenous knowledge. In: Vit P, Pedro SRM, Roubik D, editors. Pot-honey. A legacy of stingless bees. London: Springer; 2013. pp. 135-154.

155. Bringas NR. Historia de Tehuacán. De tiempos prehispánicos a la modernidad. Ciudad de México: Miguel Ángel Porrúa; 2010. p. 2010.

156. Arqueta-Villamar A, Corona-M E, Alcántara-Salinas G, Santos-Fita D, Aldasoro EM, Serrano R, Teutli C, Astorga-Domínguez M. Historia, situación actual y perspectivas de la etnozoología en México. Etnobiología. 2012;10(1):18-40.

157. Santos-Fita D, Argueta-Villamar A, Astorga-Domínguez M, QuiñonesMartínez M. La etnozoología en México: La producción bibliográfica del siglo XXI (2000-2011). Etnobiología. 2012;10(1):41-51.

158. Gutiérrez-Santillán T, Albuquerque UP, Valenzuela-Galván D, Reyes-Zepeda F Vázquez LB, Mora-Olivo A, Arellano-Mendez LU. Trends on mexican etnozoological research, vertebrates case: a systematic review. Ethnobiology and Conservation; 2019, 8:1 DOI: 10.15451/ec2019-01-8.01-1-39

159. Baraza E, Ángeles S, García A. Valiente-Banuet. New natural resources as diet supplement for domestic goats during the dry season, in the Tehuacán Valley, Mexico. Interciencia. 2008;33(12):891-6.

160. Mandujano S, Barrera-Salazar A, Vergara-Castrejon A. Similitud de especies de plantas consumidas por rebaños de cabras en el bosque tropical seco de la Cañada. Oaxaca.Rev Mex Cienc Pecu. 2019;10(2):490-505 https://doi. org/10.22319/rmcp.v10i2.4370.

161. Baraza E, Valiente-Banuet A. Efecto de la exclusión de ganado en dos especies palatables del matorral xerófilo del Valle de Tehuacán. México. 
Revista Mexicana de Biodiversidad. 2012;83:1145-51. https://doi.org/10.7550/ rmb.22871.

162. Baraza E, Valiente-Banuet A. Seed dispersal by domestic goats in a semiarid thornscrub of Mexico. Journal of Arid Environments. 2008;72(10):1973-6. https://doi.org/10.1016/j.jaridenv.2008.04.004.

163. Giordani L, Baraza E, Camargo-Ricalde SL, Moe SR. The domestic goat as a potential seed disperser of Mimosa luisana (Leguminosae, Mimosoideae) in the Tehuacán-Cuicatlán Valley, Mexico. Journal of Tropical Ecology. 2015; 31(1):91-4.

164. Rosa-García R, Celaya R, García U, Ozoro K. Goat grazing, its interactions with other herbivores and biodiversity conservation issues. Small Ruminant Research. 2012;107(2-3):49-64. https://doi.org/10.1016/j.smallrumres.2012.03.021.

\section{Publisher's Note}

Springer Nature remains neutral with regard to jurisdictional claims in published maps and institutional affiliations.

Ready to submit your research? Choose BMC and benefit from:

- fast, convenient online submission

- thorough peer review by experienced researchers in your field

- rapid publication on acceptance

- support for research data, including large and complex data types

- gold Open Access which fosters wider collaboration and increased citations

- maximum visibility for your research: over $100 \mathrm{M}$ website views per year

At $\mathrm{BMC}$, research is always in progress.

Learn more biomedcentral.com/submissions 